\title{
1929 Dünya Ekonomik Krizi döneminde hukuki açıdan İzmir Limanı*
}

\author{
The Port of İzmir from a legal perspective during \\ the 1929 World Economic Crisis period
}

\author{
Gönderim Tarihi / Received : 18.09.2020 \\ Kabul Tarihi / Accepted : :03.06.2021
}

Doi: https://doi.org/10.31795/baunsobed.796978

\section{Erdem MERAKLI ${ }^{1}$}

ÖZ: Bu çalışmanın amacı, Atatürk Dönemi'nde İzmir Limanı'nın devlet idaresi altına alınmasında rol oynayan hukuki ve ekonomik etkenleri incelemek ve değerlendirmektir. Çalışmada ayrıca, Atatürk Dönemi'nde hükümet ile yabancı sermaye arasındaki ilişkiler, İzmir Limanı'nın millileştirilmesi örneği üzerinden incelenecektir. Araştırma sonunda elde edilen bulgulardan biri, limanın hukuki durumunun değişmesinde, bir diş etken olarak Büyük Buhran'ın rol oynadığı yönündedir. Şöyle ki, Ekim 1929'da ABD'de başlayan ve hızla Avrupa'ya yayılan 1929 Dünya Ekonomik Krizi'nin etkisiyle Türkiye'de tarım ürünü fiyatları düşmüş ve dış ticaret faaliyetleri azalmıştı. İzmir Limanı ise, Cumhuriyet'in ilk yıllarında ülkenin en önemli ihracat merkezlerinden biriydi ve limandan çoğunlukla tarım ürünleri ihraç edilmekteydi. Dolayısıyla ekonomik kriz nedeniyle limandaki ihracat faaliyetlerinde düşüş yaşanmıştı. Bunun üzerine hükümet liman ile ilgili sorunları çözmek için harekete geçmişti. Dolayısıyla Büyük Buhran'ın, İzmir Limanı'nın hukuki durumunu etkilediği görülmektedir. Diğer yandan çalışma ile, İzmir Limanı'ndaki ihracat faaliyetlerine zarar veren iç etkenlerin, limanı yöneten şirketlerden kaynaklandığı tespit edilmiştir. Cumhuriyet'in ilk yıllarında, limandaki yükleme-boşaltma faaliyetlerinden Türk sermayeli İzmir Liman ve Körfez Şirketi sorumluyken, rıhtımın yönetimi ise Fransız sermayeli İzmir Rıhtımı Anonim Şirketinin elindeydi. Türk şirketin uyguladığı yükleme-boşaltma ücretleri ve Fransız şirketin ihracattan aldığı rıhtım vergisi, tüccarın maliyetini yükseltmekteydi. Bu da İzmir Limanı'ndaki ihracat faaliyetlerine zarar vermekteydi. Ayrıca Fransız şirketin karıştığı bir yolsuzluk olayı da mevcuttu. Çalışma sonucunda, 1929 Krizi'nin yanı sıra bu etkenlerin de limanın hukuki durumunda yaşanan değişimde rol oynadığ tespit edilmiştir. Bu değişim ise, hükümet tarafından Fransız şirketin yönetimindeki rıhtıma el konulması, Türk şirketin tasfiye edilmesi ve İzmir Limanı'nın bir devlet idaresi altına alınması şeklinde gerçekleşmişti. Ayrıca çalışma ile, İzmir Limanı'nın millileştirilmesinin bir yabancı sermaye karşıtlığından değil, kamu yararının gözetilmesi amacından kaynaklandığı sonucuna varılmıştır.

Anahtar Kelimeler: 1929 Dünya Ekonomik Krizi, Büyük Buhran, İzmir Limanı, Millileştirme.

"Bu çalışma, Ankara Üniversitesi Türk İnkılap Tarihi Enstitüsü Atatürk İlkeleri ve İnkılap Tarihi Anabilim Dalı'nda Prof. Dr. Bige SÜKAN danışmanlığında hazırlanan "1929 Dünya Ekonomik Buhranı ve İzmir Limanı” başlıklı Yüksek Lisans tezinin ilgili bölümünden üretilmiştir.

${ }^{1}$ Arş. Gör., Mardin Artuklu Üniversitesi/Edebiyat Fakültesi/Tarih Bölümü/Türkiye Cumhuriyeti Tarihi Anabilim Dalı, erdemmerakli@artuklu.edu.tr, https://orcid.org/0000-0003-2435-9926 
ABSTRACT: The aim of this study is to investigate and interpret the legal and economic factors that played a role in the nationalization of the Port of İzmir during Atatürk Period. The study will try to clarify the state of the relations with foreign capital during Atatürk Period with the example of the Port of Izmir's nationalization. One of the research's findings is that the Great Depression is an external factor that played a role in the change of the legal state of The Port of İzmir. 1929 Crisis, which started in the USA in October 1929 and spread to the world, caused negative developments in Turkey too. As a result of the crisis, the prices of agricultural products dropped in Turkey and Turkey's foreign trade activity decreased. The Port of İzmir was one of the country's most important exportation centers during the first years of the republic and it was mainly exporting agricultural products. So, the exportation activity in the port decreased because of the crisis. When the exports decreased, the Turkish government consequently took action to solve the problems regarding the port. Thus, the Great Depression affected the legal state of the Port of İzmir. The study determined that the internal factors that damaged the Port of Izmir's exportation activity are related to the companies that were in charge of the port. While the Turkish-funded İzmir Port and Gulf Company (İzmir Liman ve Körfez Şirketi) was in charge of loading and unloading, the French-funded İzmir Dock Inc. (İzmir Rıhtımı Anonim Şirketi) administered the dock during the Great Depression. The Turkish company's prices for loading and unloading, and the wharfage that the French company took for exportation increased the expenses of merchants and this was damaging the exportation done through the Port of İzmir. Also, there was a case of corruption that the French company was involved in. At the end of the study, it was determined that all of these factors played a role in the change in the port's legal state. The change is that the government seized the dock, closed down the Turkish company and assigned a government administration to the Port of İzmir. It was concluded with this study that, the nationalization of the Port of İzmir didn't stem from an opposition to foreign capital, but from the intention to benefit the public.

Keywords: 1929 World Economic Crisis, the Great Depression, the Port of İzmir, Nationalization. 


\section{EXTENDED ABSTRACT}

When we look at the previous studies about the Port of İmir, it is seen that there are many studies about the status of the port until 1929. For example, Mübahat Kütükoğlu has detailed studies (2000b) on the developments in the port in the 19th and early 20th centuries. In addition, in a study by Filiz Koçak (2013), the situation of commercial activities in the port in the first quarter of the 20th century was discussed. In the study of Umut Karabulut (2003), the commercial situation of the Port of İmir between the years 1923-1929 was discussed in detail. However, this study was limited to the year 1929. On the other hand, Mehmet Emin Elmacı's study (2017) focused on the corruption case involving French-funded İzmir Dock Inc. (İzmir Rıhtımı Anonim Şirketi) and the process of purchasing the dock belonging to the company by the state. In this study, unlike the previous studies, the legal and economic reasons for the port of İzmir to come under the state administration during the Atatürk Period will be examined and evaluated together. Again, unlike the previous studies, the situation of the İzmir Dock Inc. as well as the Turkish-funded İzmir Port and Gulf Company (İzmir Liman ve Körfez Şirketi) during the Great Depression will be discussed. Thus, an important gap in the literature about the historical development of the Port of İzmir, covering the years between 1929-1934, will be tried to be filled. In addition, with this study, it is aimed to contribute to the studies about the relations between the Turkish government and foreign capital and the nationalizations carried out in the Atatürk Period, with the example of the Port of İzmir. At the beginning of the 1929 World Economic Crisis, management of the Port of İzmir was legally divided into two pieces. The ferry operations and loading-unloading works at the port were under the responsibility of the İzmir Port and Gulf Company. But on the other hand, the dock in the port was under the management of the İzmir Dock Inc. The ships that arrived at the port were paying the loading-unloading fee to the Turkish company and also paying the dock tax to the French company. Therefore, this dual administration at the port was harming the trade carried out through the port. In addition to the problems arising from the companies managing the port, it is possible to say that the negative effects of the 1929 World Economic Crisis on the exports made through the port also played a role. One of the effects of the 1929 World Economic Crisis in the world was the decrease in agricultural product prices. This development also negatively affected the value of exports made through the Port of İmir. For example, the prices of three important agricultural products exported from the port, such as tobacco, grapes and figs, fell sharply during the Great Depression. And this caused a decrease in the exports that were made through the port. On the other hand, there were some internal factors in the decline in export activities at the port. One of these internal factors was the dock tax that was collected by the 
İzmir Dock Inc. This tax was increasing the cost of the traders. In addition, in the examinations made by the government in the registries of the İzmir Dock Inc., it was understood that the company did not pay the share it had to pay to the government from the dock tax revenues. Thereupon, the company was seized in January 1932. The dock, which was owned by the French company, was transferred to the İzmir Port and Gulf Company in 1933. On the other hand, there were also problems arising from the Turkish company in the port. One of these problems was the company's high loading and unloading tariffs that increased the cost of the traders. The government acted in 1934 to solve the problems arising from the Turkish company. For this purpose, İzmir Port and Gulf Company was nationalized with a law enacted in 1934. Finance Minister Fuat Bey (Ağralı) cited the fact that the port works are a public service as the reason for putting the port under the government administration. Later, with the arrangements made at the beginning of 1935, the management of the Port of İzmir was given to the General Directorate of the Port Affairs of İzmir (İzmir Liman İşleri Umum Müdürlüğü), which was established under the Ministry of Finance. The administration was given the rights to carry out the loading and unloading works at the port, to collect the dock tax, to operate the horse-drawn tram at the dock and to transport passengers. Thus, the process of putting the Port of İzmir under the state administration, which started with the seizure of the İzmir Dock Inc., was officially completed. One of the conclusions reached by this research is that the Great Depression played a role in bringing the Port of İzmir under the state administration. The decrease in exports made through the port due to the economic crisis was damaging the country's economy. Therefore, the problems that adversely affected the export activities at the port had to be resolved. At this point, it should be noted that the government took official action in January 1932. Therefore, it can be thought that the government took action to nationalize the port after the Great Depression negatively affected the foreign trade. Another conclusion reached by the study is that the practices of the İzmir Dock Inc. and the İzmir Port and Gulf Company that harmed the export activities at the port were effective in bringing the Port of İzmir under the state administration. The dock tax on exports and the high loading and unloading fees increased the cost of the trader exporting through the port. All these problems related to the management of the port created a situation that harmed the public interest. It is possible to say that the government intervened in the legal situation of the port in order to provide for the public interest. Because the Ministry of Economy and the Ministry of Finance had the view that the Port of İzmir should be managed by a state administration instead of a private company. Therefore, another conclusion reached by the study is that the reason for considering the public interest was effective in the nationalization of the Port of İzmir. In addition, after the 
government had seized the İzmir Dock Inc. in 1932, arguments were made that there was an opposition to foreign capital in Turkey. But the event that led to the seizure of the French company was the discovery that the company was corrupt. It was quite natural for the government to intervene in this situation, which harmed the country's economy. In addition, the government had also liquidated the Turkish-funded İzmir Port and Gulf Company after purchasing the dock belonging to the French company. Therefore, it has been concluded that there is a negative attitude towards private capital, not foreign capital, in the process of putting the Port of İzmir under the state administration. 


\section{Giriş}

Bu çalışmanın merkezinde yer alan "millileştirme" teriminin tanımlanması ile ilgili birçok farklı görüş bulunmaktadır. Birinci görüşe göre millileştirme, özel sektör niteliği taşıyan bir girişimin ve malların devlet mülkiyeti altına alınması anlamına gelmektedir. Buna göre, millileştirilen teşebbüsün işletilme şeklinde bir değişiklik olması gerekli değildir ve işletme kapitalist girişim niteliğini sürdürebilir. İkinci bir görüşe göre, özel sektöre ait bir girişim, eğer yönetim kurulu hükümet kontrolü altına alınırsa, devlet mülkiyetine geçirilmeden de millileştirilmiş sayılabilir. Örneğin Fransa'da, Fransız Bankası'nın mülkiyeti 1945 yılında devlete geçmişti. Fakat Fransız Hükümeti daha öncesinde, 1936 yılında çıkarılan bir kanunla Fransız Bankası'nın hissedarlarını banka yönetiminden uzaklaştırmıştı. Ardından bankanın yeni yönetim kurulu, devlet temsilcilerinden, banka personelinden ve banka hissedarlarından oluşturulmuştu. Dolayısıyla bu ikinci görüşe göre, Fransız Bankası'nın millileştirilmesi 1945'te değil, 1936'da gerçekleşmişti. Üçüncü bir görüş ise millileştirme teriminin tan1mını, hem özel teşebbüse ait malların mülkiyetinin devlete geçmesi hem de girişimin yönetiminin hükümet kontrolü altına alınması şeklinde yapmaktadır. Millileştirme terimine yönelik bu tanımlar içerisinden, en isabetli olanın üçüncü görüş olduğunu söylemek mümkündür. Zira bir teşebbüsün sadece mülkiyetinin devlete geçmesi fakat yönetim şeklinin aynı kalması, kamu yararının sağlanması için yeterli olmayabilir. Diğer yandan mülkiyetin özel sermayede kaldığ1 ancak yönetimin hükümet kontrolüne geçtiği durumlarda da kamu yararının gözetilmesi amacının ne ölçüde gerçekleşeceği şüphelidir. Dolayısıyla bir teşebbüsün millileştirilmiş olması ve kamu yararının gözetilebilmesi için her iki şart da sağlanmak zorundadır (Azrak, 1970: 46-49).

Türkiye'de Cumhuriyet'in ilk yıllarında yapılan millileştirmelerde, yukarıda bahsedilen üçüncü görüşe uygun bir şekilde, kamu yararının gözetilmesinin amaçlandığı söylenebilir. Zira bu dönemde millileştirilen şirketlerin ${ }^{1}$ çoğu, kamu yararını yakından ilgilendiren alanlarda faaliyet gösteriyorlardı. Ayrıca çalışmada ele alınacağı üzere, İzmir Limanı'nın millileştirilmesi süreci sonunda, limanın hem mülkiyeti hem de yönetimi devlete geçecekti.

1923-1950 yılları arasında Türkiye'de 24 yabancı şirket devlet tarafından satın alınmıştı. Bu 24 şirketin sekizi demiryolu ve liman², 12'si belediye hizmetleri,

\footnotetext{
${ }^{1}$ Örneğin, Cumhuriyet'in ilk yıllarında millileştirilen şirketlerden bir tanesi Alman sermayeli Anadolu Demiryolu Şirketi idi. Şirket, 4 Mart 1889 tarihinde, Deutsche Bank, Deutsche Vereinsbank ve Wüttembergische Vereinsbank'ın katılımı ile İstanbul merkezli olarak kurulmuştu. Anadolu Demiryolu Şirketi, Osmanlı topraklarında kurulan ilk Alman sermayeli demiryolu şirketiydi (Avc1, 2015: 269270). Şirket, TBMM'de 31 Aralık 1928'de kabul edilen ve 12 Ocak 1929'da yürürlüğe giren "Anadolu ve Mersin-Tarsus-Adana demir yolları ve Haydar Paşa limanı ve Zürihte şark demir yolları bankası arasında münakit dört kita itilafname ve merbutatının tasdiklerine ait kanun" ile millileştirilmişti. Böylece şirkete ait Haydarpaşa-Ankara-Adapazarı-Eskişehir-Konya-Kütahya demiryolu hattı hükümete devredilmişti (Resmî Gazete, 12 Ocak 1929).

${ }^{2}$ Liman, Yunanca kökenli bir kelimedir. Eski Yunancada "limēn/leimōn" şeklinde kullanılmakta ve sığınak, sınır, kapı gibi anlamları bulunmaktaydı (etimolojiturkce.com, 07.08.2020).
} 
ikisi imalat sanayii ile ticaret ve ikisi madencilik sektörlerine aitlerdi. Görüldüğü üzere yapılan millileştirmelerin çoğunluğu demiryolu, liman ve belediye hizmeti gibi alanlarda yapılmıştı. Yabancı şirketler bu sektörlerde kâr amacı güderek faaliyet göstermekteydiler ve bu durum kamu yararını zedelemekteydi (Tezel, 2015: 242-244). Demiryolları ve belediye hizmetlerinin yanı sıra limanlar da bulundukları bölgenin ekonomik hayatını yakından ilgilendirmeleri açısından önemlidir. Dolayısıyla Cumhuriyet'in ilk yıllarında bu sektörde yapılan millileştirmelerde de kamu yararının gözetilmesinin amaçlandığı söylenebilir.

Türkiye'de, 1920'li yıllarda liman olarak nitelendirilebilecek altı sahil noktas1 vard1. Bu sahil noktaları; İstanbul Limanı, Mersin Limanı, Samsun Liman1, Trabzon Limanı, Karadeniz Ereğlisi Limanı ve İzmir Limanı ${ }^{3}$ idi. Bu limanlar Karadeniz, Ege ve Akdeniz'deki ticaret yollarının üzerindeydiler. Ayrıca İç Anadolu ve İran gibi iç bölgelere ulaşan ticarette önemli bir role sahiptiler (BCA, 30.10.0.0.27.153.2). Bu limanlar içerisinde İzmir Limanı, çalışmanın ilerleyen bölümlerinde ele alınacağı üzere, hem Osmanlı döneminde hem de Cumhuriyet döneminde ülkenin en önemli ihracat merkezlerinden biriydi. Liman üzerinden ihraç edilen ürünlerin çoğunluğunu, Batı Anadolu'da üretilen tarım ürünleri oluşturmaktaydı. Fakat 1929 yılında başlayan Büyük Buhran nedeniyle dünyada hem uluslararası ticaret azalmış hem de tarım ürünleri fiyatları düşmüştü. Bu da İzmir Limanı üzerinden yapılan dış ticareti olumsuz yönde etkilemişti. Fakat ekonomik kriz, İzmir Limanı'nın sadece dış ticaretinde değil, hukuki durumunda da değişime yol açmıştı.

İzmir Limanı ile ilgili daha önce yapılmış çalışmalara göz atıldı̆̆ında limanın 1929 yılına kadarki durumuyla ilgili birçok çalışmanın bulunduğu görülmektedir. Örneğin, Mübahat Kütükoğlu'nun limanda 19. yüzyılda ve 20. yüzyıl başlarında yaşanan gelişmelere dair ayrıntılı çalışmaları (2000b) bulunmaktadır. Ayrıca Filiz Koçak'ın bir çalışmasında (2013) limandaki ticari faaliyetlerin 20. yüzyılın ilk çeyreğindeki durumu ele alınmıştır. Umut Karabulut'un çalışmasında (2003) ise İzmir Limanı'nın 1923-1929 yılları arasındaki ticari durumu ayrıntılı bir şekilde ele alınmıştır. Fakat bu çalışma, 1929 yılı ile sınırlandırılmıştır. Diğer yandan Sadık Kurt'un çalışmasında (2012), Büyük Buhran yıllarında İzmir Limanı'nda faaliyet gösteren şirketlerden, Fransız sermayeli İzmir Rıhtımı Anonim Şirketinin ve Türk sermayeli İzmir Liman ve Körfez Şirketinin genel hatlarıyla ele alındığı görülmektedir. Ayrıca, Mehmet Emin Elmacı'nın çalışmasında (2017), İzmir Rıhtımı Anonim Şirketinin karışmış olduğu yolsuzluk olayına ve şirkete ait olan rıhtımın devlet tarafından satın alınma sürecine odaklanılmıştır.

Bu çalışmada, daha önceki çalışmalardan farklı olarak, Atatürk Dönemi'nde İzmir Limanı'nın devlet idaresi altına alınmasının hukuki ve ekonomik nedenleri birlikte incelenecek ve değerlendirilecektir. Yine önceki çalışmalardan farklı olarak, Fransız sermayeli İzmir Rıhtımı Anonim Şirketinin yanı sıra Türk

\footnotetext{
${ }^{3}$ İzmir Limanı'nın 1935 tarihli haritası Ek-1'de verilmiştir.
} 
sermayeli İzmir Liman ve Körfez Şirketinin de Büyük Buhran yıllarındaki durumu ele alınacaktır. Böylece, İzmir Limanı'nın tarihsel gelişimine ilişkin literatürde, 1929-1934 yılları arasını kapsayan önemli bir boşluk kapatılmaya çalışılacaktır. Ayrıca bu çalışma ile, Atatürk Dönemi'nde yabancı sermaye ile ilişkiler ve gerçekleştirilen millileştirmeler hakkındaki çalışmalara, İzmir Limanı örneğiyle katkı sağlanması amaçlanmaktadır.

Çalışmanın birinci bölümünde, İzmir Limanı'nın tarihsel gelişim süreci ile Osmanlı Devleti'nin son dönemindeki ve Cumhuriyet'in ilk yıllarındaki hukuki durumundan bahsedilecektir. İkinci bölümde, 1929 Dünya Ekonomik Krizi'nin İzmir Limanı aracılığıyla yapılan ihracat faaliyetleri üzerindeki etkileri incelenecek ve değerlendirilecektir. Üçüncü bölümde, Büyük Buhran yıllarında İzmir Limanı'ndaki rıhtımın yönetiminden sorumlu olan Fransız sermayeli İzmir Rıhtımı Anonim Şirketi ve İzmir Limanı'nda yükleme-boşaltma ve yolcu taşımacılığı faaliyetlerinden sorumlu olan Türk sermayeli İzmir Liman ve Körfez Şirketi ile ilgili sorunlar işlenecektir. Çalışmanın dördüncü bölümünde ise, Fransız sermayeli şirkete ait rıhtımın devlet tarafından satın alınması ve Türk sermayeli şirketin tasfiye edilmesi süreçleri incelenecektir. Çalışmanın hazırlanmasında 1929-1934 yıllarına ait arşiv belgelerinden, istatistik yıllıklarından, İzmir Ticaret ve Sanayi Odası Mecmuası sayılarından, İzmir' in yerel basınından ve ulusal basından yararlanılmıştır.

\section{İzmir Limanı'nın tarihsel gelişim süreci}

İzmir Limanı'nın tarihteki gelişim sürecine geçmeden önce, limanların genel özelliklerinden bahsetmekte yarar vardır. Gemilerin dalga ve rüzgâr gibi olumsuz etkenlere karşı muhafaza edildikleri yerler olan limanların fiziki yapıları su ve kara alanları olmak üzere ikiye ayrılmaktadır. Limanların su alanlarının derinliği, gemilerin güvenli bir şekilde kıyıya yanaşabilmeleri bakımından önemlidir. Limanların karadaki kısmında ise rıhtım, antrepo, depo ve çeşitli hizmet binaları bulunmaktadır. Ayrıca limanların etrafında kara ile bağlantılı bir tür set olan mendirekler veya kara ile bağlantısı olmayan dalgakıranlar vardır. Bunlar, limana yanaşmış olan gemileri dalgalardan korumaktadırlar. Limanlarda çoğunlukla malların yükleme-boşaltma işlemleri yapılmakta fakat bununla beraber yolcu taşımacılığı faaliyetleri de yürütülebilmektedir (Öner, 2015: 3-5).

Limanların kara alanlarında bulunan tesislerin başında rıhtımlar ve iskeleler gelmektedir. Rıhtımlar, kıyı çizgisi boyunca sahile paralel bir şekilde inşa edilmişlerdir. İskeleler ise kıyı çizgisine dik bir şekilde inşa edilmiş yapılardır. Hem rıhtımlarda hem de iskelelerde mal yükleme-boşaltma işlemleri yapılabilmektedir. Limanların kara alanında faaliyet gösteren diğer tesislerden antrepolar, malların uzun süreli bir şekilde depolanmaları işlevini görmektedirler. Limanlarda bulunan diğer yapılar ise gümrük, merkez yönetim ve liman 
güvenliği binalarıdır (Öner, 2015: 8-12). Limanların genel hatlarıyla özellikleri bu şekildeyken, Cumhuriyet'in ilk yılları itibariyle Türkiye'nin dış ticaretinde önemli bir yere sahip olan İzmir Limanı, tarihteki gelişim süreci boyunca ticari açıdan birçok iniş ve çıkış dönemi yaşamıştı. İzmir Limanı'nın tarih sahnesine çıkışını, İzmir şehrinin kuruluşu ile başlatmak mümkündür.

İzmir şehrinin ilk kuruluşu M.Ö. 3000'lerde, günümüzde İzmir'in Bayraklı ilçesinin bulunduğu yerdeki Tepekule'de gerçekleşmişti. Eski İzmir'in limanının da burada olduğu düşünülmektedir (Baykara, 1974: 25). İyonların ${ }^{4}$ 8. yüzyılda İzmir'e hâkim olmaları ile şehir İyon ticaret ağına dâhil olmuştu (Ünal, 2015a: 44-45). Bölgede yapılan kazılardan elde edilen bilgilere göre şehirde bu döneme ait Kıbrıs yapımı eserler bulunmaktaydı (Aksoy, 2002: 37). İzmir Limanı aracılığıyla yapılan ticari faaliyetler İyon hâkimiyeti döneminde hızla artmıştı. Fakat M.Ö. 7. yüzyılda Lidyalılar şehre saldırı düzenlemişlerdi (Baykara, 1974: 68). Ardından M.Ö. 6. yüzyılda Perslerin de şehri yağmalamalarının etkisiyle İzmir'de büyük bir tahribat meydana gelmişti. Şehir bu saldırılardan sonra zenginliğini kaybetmişti (Ünal, 2015a: 45). İzmir şehrinin ikinci kuruluşu ise M.Ö. 4. yüzyılda Pagos Dağı'nda ${ }^{5}$ gerçekleşmişti (Ünal, 2015a: 46). Şehir, M.Ö. 3. yüzyılda Bergama Krallığının, ardından M.Ö. 2. yüzyılda Roma İmparatorluğunun hâkimiyetine girmişti. Böylece İzmir şehri Roma-Anadolu arasındaki ticarette ön plana çıkan şehirlerden biri olmaya başlamıştı (Baykara, 1974: 70). İzmir, M.S. 395’te Roma İmparatorluğu ikiye bölündüğünde Doğu Roma İmparatorluğu hâkimiyetinde kalmıştı. Doğu Roma Dönemi'nde İzmir Limanı bir donanma üssü olarak kullanılmıştı (Baykara, 1974: 70-71). İzmir şehrindeki Doğu Roma egemenliği 11. yüzyıl sonlarındaki Çaka Bey ${ }^{6}$ Dönemi (1081-1098) haricinde 14. yüzyılın ilk çeyreğine kadar sürmüştü. 1326 yılında İzmir şehri bütünüyle Aydınoğulları hâkimiyetine girmiş fakat kısa bir süre sonra 1344'te Aşağı Kale (Liman Kalesi ve İzmir Limanı) Haçlıların eline geçmişti. Yukarı Kale (Kadifekale) ise Müslümanların elinde kalmıştı. Böylece şehir, Aşağı İzmir ve Yukarı İzmir olmak üzere ikiye bölünmüştü. Bu durum İzmir Limanı ticaretini olumsuz yönde etkilemişti. Zira İzmir Limanı ve denizyolu Haçlıların, limana giden karayolu ise Türklerin egemenliğindeydi. 1390'da Osmanlılar Aydınoğullarını mağlup ederek Yukarı İzmir'de hâkimiyet kurmuşlarsa da 1402'de Timur ${ }^{7}$ Osmanlıları ve Haçlıları İzmir'den çıkarmıştı. Daha sonra

\footnotetext{
${ }^{4}$ İyonların kökenlerinin Atina'ya dayandığı ve M.Ö. 1000 yakınlarında Anadolu'ya geldikleri düşünülmektedir (Işık, 2009: 65).

${ }^{5}$ Pagos Dağı, İzmir sahilinden birkaç kilometre içeride İzmir şehir merkezinde yer almaktadır (Atay, 1998: 181).

${ }^{6}$ Çaka Bey, 1071'de Doğu Roma ve Selçuklular arasında yaşanan Malazgirt Muharebesi'nden önce Anadolu'ya akınlar yapmış fakat Doğu Roma'ya esir düşmüş bir Türk beyiydi. Daha sonra Doğu Roma içerisindeki taht kavgalarından faydalanarak kaçmış ve Batı Anadolu'da fetihler yapmıştı (Ünal, 2015b: 33).

${ }^{7}$ Timur, kurucusu olduğu Timur Devleti'nin başına 1370 yılında Cengiz Han soyundan birini getirmiş ancak devleti fiili olarak kendisi yönetmişti. Timur Devleti'nin sınırları Anadolu'dan Hindistan'a ka-
} 
Timur, Aşağı İzmir'i ve Yukarı İzmir'i Aydınoğullarına vermişti. 1425 yılında ise Osmanlılar Aydınoğullarını mağlup ederek İzmir'de kesin hâkimiyetlerini sağlamışlardı (Ünal, 2015a: 48-49). İzmir şehrinin bütünüyle Osmanlı egemenliği altına girmesinin, İzmir Limanı'nın gelişimi açısından önemli bir dönüm noktası olduğunu söylemek mümkündür. Zira böylece şehirde siyasi istikrar ve güvenlik tesis edilmişti. Bu da İzmir Limanı üzerinden yapılan ticaretin gelişmesini sağlayan etkenlerden biri olmuştu.

16. yüzyıl itibariyle İzmir Limanı, Osmanlı limanları arasındaki iç ticarette önemli bir yere sahipti (Kütükoğlu, 2000a: 35). Ancak liman bu yüzyılda Avrupa ile yapılan dış ticarette Çeşme Limanı'nın gerisindeydi (Kütükoğlu, 2000b: 286). 17. yüzyıla gelindiğinde ise, İzmir Limanı dış ticarette Batı Anadolu'nun en önemli limanı olmuştu (Goffman, 1990/1995: 125). Limanın 17. yüzyılda yaşadığı hızlı gelişmede 1623 yılında Osmanlı Devleti'nin İzmir'den Avrupa'ya pamuk ihraç edilmesine izin vermesi önemli bir rol oynamıştı (Ünal, 2015a: 80). Ayrıca İran-Avrupa arasındaki ipek ticaretinin İzmir'e yönelmesi de İzmir Limanı ticaretinin hızla canlanmasına katkıda bulunmuştu (Goffman, 1990/1995: 126). İzmir Limanı ticaretindeki canlılık 18. yüzyılda da devam etmişti. Bu yüzyılda ABD'nin İngiltere'den bağımsızlı̆̆ını kazanması, Batı Anadolu'nun ve dolayısıyla İzmir Limanı'nın öneminin artmasında etkili olmuştu. Şöyle ki, bu dönemde İngiltere'nin ABD'den temin etmekte olduğu ham maddelerin başında pamuk gelmekteydi. ABD'nin bağımsızlığı sonrasında ise İngilizler pamuk için yeni bir kaynak arayışına yönelmişlerdi. Bu da pamuk üretimi yapılan Batı Anadolu'nun önemini arttırmıştı (Kasaba, 1994: 8-9). İzmir Limanı'ndaki dış ticaretin gelişimi 19. yüzyılda, önceki yüzyıllara göre daha da hızlandı. Bunda, 18. yüzyıl sonlarında İngiltere'de ortaya çıkan ve 19. yüzyıl boyunca Avrupa'ya yayılan Sanayi Devrimi önemli bir etkendi (Önsoy, 1988: 11-12). Sanayi Devrimi'nin etkisiyle Batı Avrupa devletleri 19. yüzyılda yeni ham madde kaynağı arayışlarını hızlandırdılar. Bu da Osmanlı-Avrupa arasındaki ticari ilişkileri hızla geliştirdi (Pamuk, 1988: 186, 199). Bu gelişmede, Osmanlı Devleti'nin ham madde kaynaklarının zengin oluşu etkiliydi (Önsoy, 1988: 12). Sanayi Devrimi'nin yanı sıra Osmanlı Devleti'nin 19. yüzyılda Avrupa devletleri ile imzaladığı serbest ticaret anlaşmalarının da Osmanlı-Avrupa arasındaki ticareti geliştiren etkenlerin başında geldiğini söylemek mümkündür.

Osmanlı Devleti 1838-1846 yılları arasında İngiltere, Fransa, Sardunya, Danimarka, İsveç, Portekiz ve Rusya ile serbest ticaret anlaşmaları yaptı (Sükan, 2014: 198). Bu anlaşmalar ile yabancı devletlere ticari hayatta yeni ayrıcalıklar tanındı. Örneğin, 1838'de İngiltere ile imzalanan Balta Limanı Ticaret Anlaşması'na göre, İngiliz tüccar Osmanlı toprakları içerisinde yapılan ticaretten alınan iç gümrük vergisinden muaf tutuldu. Öte yandan yerli tüccar iç gümrük

dar uzanmaktaydı (Yüksel, 2004: 85-86). 
vergisini ödemeye devam etti. Bu da yerli tüccarın iç ticarette yabancı tüccar ile rekabet etmesini zorlaştırdı (Memiş, 2008:89). Anlaşmada ihracat ve ithalat tarifeleri de belirlendi. Anlaşma öncesinde Osmanlı Devleti bazı ürünlerin ihracat vergisini yüksek tutuyordu. Örneğin, zeytinyağ1 ihracatından \%33 oranında vergi alınıyordu. Fakat Balta Limanı Ticaret Anlaşması ile gümrük vergileri ihracatta \%12, ithalatta \%3 olarak belirlendi. Gümrük vergilerinin düşük tutulduğu bu anlaşma sonrasında Osmanlı ülkesi Avrupa devletleri için bir açık pazar konumuna geldi. Bu da Sanayi Devrimi'nin Osmanlı imalat sektörü üzerindeki olumsuz etkilerinin daha da güçlenmesine yol açtı (Eşiyok, 2010: 77-87). Fakat diğer yandan serbest ticaret anlaşmalarının etkisiyle Osmanl1-Avrupa arasındaki ticaret hızla gelişti. Bu gelişme, İzmir Limanı'nın dış ticaret rakamlarına da yansıdı. Örneğin, 1837-1850 yılları arasında İzmir Limanı üzerinden yapılan ihracat 967.000 sterlinden 1.449 .000 sterline, ithalat ise 322.000 sterlinden 1.241.000 sterline yükseldi (Tatar, 2012: 202). Ayrica Osmanlı Devleti, Batılı devletlerle 1861-1862 yıllarında da yeni serbest ticaret anlaşmaları imzaladı. Bu anlaşmalar ABD, Fransa, İngiltere, Belçika, İtalya, Rusya, İsveç, İspanya, Prusya, Hollanda ve Avusturya ile yapıldı (Sükan, 2014: 199). Anlaşmaların etkisiyle 1860-1863 yılları arasında İzmir Limanı aracılığıyla yapilan ihracat 1.846.000 sterlinden 4.955.000 sterline, ithalat ise 2.387.000 sterlinden 3.739.000 sterline yükseldi (Tatar, 2012: 202). ${ }^{8}$

İzmir Limanı'ndaki ticari faaliyetlerin gelişmesi, şehrin sosyal yapısına da yansıd1. Şehirdeki yabancı tüccar sayısı hızla arttı. Örneğin, İzmir'deki İngiliz tüccar sayısı 1849'da 202 iken bu sayı 1856'da 1061'e yükseldi. Ayrıca 1872 yılına ait bir istatistiğe göre, İzmir'de yaşayanların; 100.000'i Türkçe, 100.000'i Rumca, 30.000'i İtalyanca ve İspanyolca, 20.000'i Fransizca, 12.000'i İngilizce ve 10.000'i Arapça konuşuyordu (Yorulmaz, 1993: 136-143). 19. yüzyılda İzmir Limanı'ndaki dış ticaret faaliyetlerinin artması, şehirdeki sosyal yapıyı etkilediği kadar limanın fiziki yapısında yaşanan değişimlerde de rol oynamıştı. Ticaretin gelişmesi, limanda modern bir rıhtım inşa edilmesi ihtiyacını doğurmuştu. Bu da limanın hukuki durumunda değişime yol açmıştı. 19. yüzyılda İzmir Limanı'nın hukuki durumunda yaşanan değişim, limanın Cumhuriyet'in ilk yıllarındaki durumunu da etkilemişti. Dolayısıyla İzmir Limanı'nın Büyük Buhran yıllarındaki hukuki durumunun daha iyi değerlendirilebilmesi için 19. yüzyıldaki gelişmeler üzerinde durmakta fayda vardır.

İzmir Limanı 19. yüzyıla kadar modern bir rıhtımdan yoksun durumdaydı. Limanda sahil boyunca uzanan evler ve tüccarların kendi gayretleriyle taş ve ağaçtan yaptıkları basit bir rıhtım bulunmaktaydı (Pınar, 1998: 34). İzmir Li-

\footnotetext{
${ }^{8}$ Bu noktada belirtmekte fayda var ki, İzmir Limanı'nın yanı sıra Anadolu'daki diğer limanların da dış ticaret hacimleri 19. yüzyılda hızla arttı. Örneğin, ihracatta öne çıkan beş büyük limanın (İzmir, Trabzon, Samsun, Mersin ve İskenderun) toplam ihracatı 1837-39 yıllarında yaklaşık 1,7 milyon sterlin civarındayken bu rakam 1850-52 yıllarında 2,4 milyon sterline ve 1864-66 yillarında 6,3 milyon sterline çıtı (Topuz, 2009: 116).
} 
manı'na modern bir rıhtım inşa edilmesi için John Charnaud, George Guarracino ve Alfred Barker adlı üç İngiliz girişimci tarafından İzmir Rıhtımı Anonim Şirketi kuruldu. 1867 yılında Osmanlı Hükümeti tarafından şirkete, rıhtımın inşa edilmesi ve işletilmesine dair 30 yıl süreli bir imtiyaz verildi. Şirket, rıhtımda mal boşaltan ve yükleyen gemilerden rıhtım vergisi alacak ve bu gelirin \%12'sini devlete verecekti. Fakat inşaatın başlangıcında maddi zorluklarla karşılaşıld1. Bunun üzerine Fransız Dussaudlar ${ }^{9} 1869^{\prime}$ da olaya müdahil olarak İzmir Rıhtımı Anonim Şirketini satın aldı. Böylece rıhtım imtiyazı Fransızların eline geçti ve rıhtımın yapımına devam edildi (Kütükoğlu, 2000b: 205-212). İzmir Limanı'ndaki rıhtımın inşaatı 1876'da tamamlanmıştı. 1878 yılında ise, Fransız şirketin İzmir Limanı'nda yapmayı üstlendiği bazı inşaat işleri karşılığında imtiyaz süresine 15 yıl daha eklenmişti. Böylece rıhtım imtiyazının süresi 1912 yılına uzatılmıştı (Kütükoğlu, 2000b: 218-219). Daha sonra 1891 yılında Osmanlı Hükümeti ile İzmir Rıhtımı Anonim Şirketi arasında yeni bir anlaşma yapılmıştı. Anlaşma ile imtiyaz süresine 31 Aralık 1912 tarihinden itibaren geçerli olmak üzere 40 yıl eklenmişti. Karşılığında ise şirketin rıhtım vergisinden elde ettiği gelirden Osmanlı Hükümetine vereceği pay \%12'den \%50'ye yükseltilmişti. Ayrıca Osmanlı Hükümeti 1 Ocak 1913'ten itibaren rıhtımı satın alabilecekti (Kütükoğlu, 2000b: 233-234).

Cumhuriyet'in ilk yıllarına gelindiğinde İzmir Rıhtımı Anonim Şirketi, İzmir Limanı'nda faaliyetlerine devam etmekteydi. Fakat diğer yandan 15 Nisan 1925 tarihinde İzmir Limanı'nda yeni bir şirket, İzmir Liman ve Körfez Şirketi (İzmir Liman İşleri İnhisarı Türk Anonim Şirketi) kurulmuştu. Hükümet ile şirket arasında 30 Haziran 1925'te imzalanan imtiyaz sözleşmesine göre şirkete, İzmir Limanı'nda yolcu taşımacılığı yapma, malların gemilere yüklenmesi ve gemilerden boşaltılması hakları verilmişti. Şirket hisselerinin \%98'i hükümete aitti. Şirketin yönetim kurulu başkanı ise Dr. Hulusi Bey (Alataş) idi (Kurt, 2012: 210-211).

Bu noktada görülmektedir ki, Cumhuriyet'in ilk yılları itibariyle İzmir Limanı'nın yönetimi hukuki açıdan ikiye bölünmüş durumdaydı. İzmir Limanı'nda vapur işletmeciliği yapma ve yükleme-boşaltma işleri, Türk sermayeli İzmir Liman ve Körfez Şirketinin sorumluluğundaydı. Fakat diğger yandan limandaki rıhtım, Fransız sermayeli İzmir Rıhtımı Anonim Şirketinin yönetimindeydi. Çalışmanın ilerleyen bölümlerinde bahsedileceği üzere her iki şirket de limandaki bu işler karşılığında ücret almaktaydılar. İzmir Limanı'na gelen gemiler, Türk şirketine yükleme-boşaltma ücreti öderlerken ayrıca limandaki Fransız şirkete de rıhtım vergisi ödemekteydiler. Dolayısıyla İzmir Limanı'ndaki bu ikili yönetim, liman üzerinden yapılan ticarete zarar vermekteydi. Fakat bu

\footnotetext{
${ }^{9}$ Dussaudlar, daha önce Marsilya Limanı'nın inşaatında ve Süveyş Kanalı'nın açılmasında rol almışlardı. İzmir Rıhtımı Anonim Şirketi de İzmir Limanı'na yapılacak rıhtımın inşası için Dussaudlar ile anlaşmıştı (Kütükoğlu, 2000b: 211).
} 
durum Büyük Buhran yıllarında değişecekti. Bunda, limanı yöneten şirketlerden kaynaklanan sorunların yanı sıra, İzmir Limanı üzerinden yapılan ihracatın 1929 Dünya Ekonomik Krizi'nden olumsuz etkilenmesinin de rol oynad1ğını söylemek mümkündür.

\section{Büyük Buhran döneminde İzmir Limanı'nda ihracat faaliyetleri}

Büyük Buhran yıllarında İzmir Limanı'nın hukuki durumunda yaşanacak değişim sürecini incelemeden önce, İzmir Limanı'nın kriz yıllarındaki ihracat faaliyetlerini ele almakta fayda vardır. Zira ekonomik krizin İzmir Limanı'ndaki ihracat faaliyetlerine etkilerinin, limanın devlet idaresi altına alınmasında dolaylı bir rol oynadığı söylenebilir.

Büyük Buhran, Ekim 1929'da New York Borsası'nda yaşanan çöküntü ${ }^{10}$ ile başlamıştı. 1920'li yılların sonlarına doğru ABD piyasasında mallara olan talep, arzın altına düşmüştü. Bu talep düşüklüğü nedeniyle üreticilerin satışları azalmış, bundan dolayı üreticiler üretimlerini azaltmaya başlamışlardı. Üretimin azalması ise işsizliği doğurmuş ve artan işsizlik, halkın alım gücünün giderek düşmesiyle sonuçlanmıştı. Bu da mallara olan talebin daha çok düşmesine yol açmıştı. Diğer yandan mallarını satamayan üreticiler, bankalara olan borçlarını ödeyebilmek için hisse senetlerini satmaya başlamışlardı. Sonunda bu hisse senedi satışları New York Borsası'nda bir panik başlatmıştı. Bankalar, panik dalgasını durdurmak ve hisse senedi fiyatlarını yüksekte tutmak amacıyla hisse senetlerini yüksek değerler üzerinden satın almaya çalışmıslardı. Fakat bu müdahale, bankaların iflasına yol açmış ve krizi daha da derinleştirmişti (Gözcü, 2013: 96-97). New York Borsası'nda 24 Ekim 1929'da 13 milyon hisse senedi, 29 Ekim 1929'da ise 16,5 milyon hisse senedi değer kaybına uğrayarak satılmıştı (Néré, 1968/1980: 58).

Diğer yandan Birinci Dünya Savaşı sonrasında Avrupa ülkeleri, ekonomilerini ABD'den aldıkları borçlarla dengelemekteydiler. Fakat New York Borsası'nda yaşanan çöküşle birlikte ABD'den Avrupa'ya para akışı hızlı bir şekilde azalmıştı. Bu da Avrupa devletlerinin ekonomik dengelerini bozmuş ve krizin Avrupa'ya yayılmasıyla sonuçlanmıştı (Tekeli ve İlkin, 1977: 13). ABD'den Avrupa'ya olan para akışının azalmasının önemli bir göstergesi, Almanya merkez bankası Reichsbank'ın altın ve döviz rezervlerinin durumuydu. Zira Reichsbank, Büyük Buhran öncesinde ABD'den gönderilen kredilerin Avrupa'da toplandığı yerdi. Ocak 1929 'da bankanın altın ve döviz rezervi 2,8 milyar mark civarındayken bu rakam Ocak 1932'de 1,1 milyar mark civarına gerilemişti (Néré, 1968/1980: 77-78).

\footnotetext{
10 "Çöküntü" veya "depression", büyüme oranında olağandışı ve sürekli bir şekilde düşüşlerin gerçekleşmesi ve işsizlik oranının yüksek olduğu ekonomik bunalım durumudur (İktisat Terimleri Çalışma Grubu, 2011: 87).
} 
Büyük Buhran'ın ABD ve Avrupa'daki etkilerinden biri, sanayi üretiminde yaşanan düşüş olmuştu. Örneğin sanayi üretim endeksi ${ }^{11} 1929$ y1lı için 100 olarak kabul edilen hesaplamaya göre, 1929-1932 yılları arasında ABD'de 100'den 55'e, Almanya'da 100'den 59'a ve İngiltere'de 100'den 89'a düşmüştü (Işık ve Duman, 2012: 245). Krizin ABD ve Avrupa'daki bir başka etkisi ise, işsizlik oranlarının artması olmuştu. İşsizlik oranları 1929-1932 yılları arasında ABD'de \%3,2'den \%23,6'ya (Amadeo, 2020), Almanya'da \%13,3'ten \%43,8'e ve İngiltere'de \%10,4'ten \%22,1'e yükselmişti (Işık ve Duman, 2012: 247). Büyük Buhran'ın dünyadaki etkilerinden bir tanesi de diş ticaret hacimlerinin küçülmesi olmuştu. 1929 yılında dünya genelinde ülkeler arasında yaklaşık 33 milyar dolar değerinde ihracat yapılırken bu rakam 1932 yılında 12,7 milyar dolara gerilemişti (United Nations Statistics Division, 1962: Tablo 1).

Ayrıca 1929 Dünya Ekonomik Krizi yıllarında dünyada tarımsal ürün fiyatları da düşmüştü. Bunda, ülkelerin alım güçlerinin azalması nedeniyle dünya genelinde tarımsal ürünlere olan talebin düşmesi rol oynamıştı. Tarımsal ürün fiyatlarında yaşanan gerileme, tarım ürünleri ihracatçısı olan Türkiye'nin ihracat gelirlerinde azalma yaşanmasına yol açmıştı (Tokgöz, 2007: 60).

Tablo 1: 1927-1933 yılları arasında başlıca tarım ürünlerinin fiyatlarındaki değişim ${ }^{12}$

\begin{tabular}{lccccccc}
\hline Ürün & $\mathbf{1 9 2 7}$ & $\mathbf{1 9 2 8}$ & $\mathbf{1 9 2 9}$ & $\mathbf{1 9 3 0}$ & $\mathbf{1 9 3 1}$ & $\mathbf{1 9 3 2}$ & $\mathbf{1 9 3 3}$ \\
\hline Afyon & 100 & 81.1 & 104.6 & 70 & 35.3 & 35.2 & 31.2 \\
\hline İncir & 100 & 97.4 & 116.9 & 85.6 & 84.6 & 50.8 & 46.1 \\
\hline Pamuk & 100 & 111.2 & 109.4 & 77.9 & 58.5 & 47.4 & 45.8 \\
\hline Tütün & 100 & 70.4 & 55.9 & 59.6 & 41.6 & 33.3 & - \\
\hline Üzüm & 100 & 82 & 83.3 & 76 & 93.3 & 76.5 & 36.8 \\
\hline
\end{tabular}

Kaynak: Afyon ve üzüm maddelerine ait veriler için: Varlık, 1981: 89. Incir, pamuk ve tütün maddeleri için: Varlık, 1980: 114.

Yukarıdaki tabloda görüldügü üzere, tarım ürünleri fiyatlarında önemli düşüşler gerçekleşti. Yaşanan bu düşüşler Türkiye'nin ihracat gelirlerini olumsuz etkiledi. Türkiye' nin ihracat geliri 1929-1933 yılları arasında yaklaşık 155,2 milyon TL'den 96,1 milyon TL civarına düştü (T.C. İstatistik Yıllığı 1939-1940: 265). Fakat diğer yandan ihracat miktarı 1929 'da 669.00 ton iken bu rakam 1933 'te 719.000 tona yükseldi (Tekeli ve İlkin, 2009: 34-35). Görüldüğü üzere 1929-1933 yılları arasında ihracat miktarı artmasına rağmen ihracat geliri azaldı. Bunda Türkiye'nin ihraç ettiği tarımsal ürünlerin fiyatlarında yaşanan düşüş etkiliydi (Tekeli ve İlkin, 1977: 89). Büyük Buhran yıllarında Türkiye'nin ihracatındaki genel durum böyleyken bu dönemde İzmir Limanı üzerinden yapılan ihracatta da önemli değişimler yaşandı.

\footnotetext{
${ }^{11}$ Endeks, bir olgunun değer açısından yaşadığı değişimin temel alınan bir dönemdeki değerine göre açıklanmasıdır. (İktisat Terimleri Çalışma Grubu, 2011: 112).

12 Ürünlerin değerleri, 1927 yılı için 100 kabul edilmiş olup endeks şeklinde verilmiştir.
} 
Tablo 2: 1929-1933 yılları arasında İzmir Limanı üzerinden yapılan ihracat

\begin{tabular}{ccc}
\hline Y11 & Değer (TL) & Miktar (Kg) \\
\hline $\mathbf{1 9 2 9}$ & 80.853 .923 & 193.285 .622 \\
\hline $\mathbf{1 9 3 0}$ & 62.187 .261 & 173.372 .021 \\
\hline $\mathbf{1 9 3 1}$ & 43.268 .584 & 158.886 .075 \\
\hline $\mathbf{1 9 3 2}$ & 40.618 .162 & 180.167 .697 \\
\hline $\mathbf{1 9 3 3}$ & 32.350 .692 & 193.615 .643 \\
\hline
\end{tabular}

Kaynak: 1929 yılının verileri için: T.C. İzmir Ticaret ve Sanayi Odası Mecmuası, Haziran 1930: 341. 1930-1931 yıllarının verileri için: T.C. İzmir Vilayeti İstatistik Yıllığ1 1932-1933: 94. 1932-1933 yıllarına ait veriler için: T.C. İzmir Vilayeti İstatistik Yıllığ1 1933-1934: 112.

Tablo 3: 1929-1933 yılları arasında İzmir Limanı üzerinden ihraç edilen bazı ürünlerin ihracat değerlerinde ve miktarlarında yaşanan değişim

\begin{tabular}{lcccccc}
\hline Ürünler & & $\mathbf{1 9 2 9}$ & $\mathbf{1 9 3 0}$ & $\mathbf{1 9 3 1}$ & $\mathbf{1 9 3 2}$ & 1933 \\
\hline \multirow{2}{*}{ Afyon } & $\mathrm{TL}$ & 4.973 .953 & 2.380 .215 & 1.682 .675 & 1.103 .435 & 1.992 .933 \\
\cline { 2 - 7 } & $\mathrm{Kg}$ & 212.952 & 221.387 & 217.052 & 141.024 & 266.119 \\
\hline \multirow{2}{*}{ İncir } & $\mathrm{TL}$ & 8.161 .592 & 5.486 .074 & 5.247 .303 & 3.571 .011 & 3.776 .389 \\
\cline { 2 - 7 } & $\mathrm{Kg}$ & 23.838 .700 & 22.588 .157 & 23.777 .261 & 23.437 .991 & 25.810 .611 \\
\hline \multirow{2}{*}{ Pamuk } & $\mathrm{TL}$ & 2.704 .908 & 2.672 .660 & 965.317 & 473.145 & 563.345 \\
\cline { 2 - 7 } & $\mathrm{Kg}$ & 3.547 .342 & 4.425 .884 & 2.296 .819 & 1.341 .138 & 1.369 .934 \\
\hline \multirow{2}{*}{ Tütün } & $\mathrm{TL}$ & 26.114 .085 & 26.103 .105 & 12.688 .946 & 16.463 .995 & 10.557 .086 \\
\hline \multirow{2}{*}{ Üzüm } & $\mathrm{Kg}$ & 18.922 .830 & 16.957 .494 & 10.209 .594 & 17.396 .395 & 12.767 .870 \\
\cline { 2 - 7 } & $\mathrm{TL}$ & 17.445 .744 & 10.999 .119 & 8.895 .901 & 10.169 .053 & 6.857 .445 \\
\hline
\end{tabular}

Kaynak: 1929 yılının verileri için: T.C. İzmir Ticaret ve Sanayi Odası Mecmuası, Haziran 1930: 337-338. 1930-1931 yıllarının verileri için: T.C. İzmir Vilayeti İstatistik Yıllı̆̆ 1932-1933: 94. 1932-1933 yıllarına ait veriler için: T.C. İzmir Vilayeti İstatistik Yıllığ1 1933-1934: 112.

Tablo 2'de görüldügü gibi, İzmir Limanı'ndan yapılan ihracat miktar olarak 1929-1931 yılları arasında azaldı. Bunda 1929-1931 yıllarının ekonomik krizin ağır bir şekilde yaşandığı yıllar olması rol oynadı. Çalışmada daha önce bahsedildiği üzere ABD ve Avrupa'nın Büyük Buhran nedeniyle alım gücü düştü. Bu da İzmir Limanı ihracatını olumsuz etkiledi. Zira bu dönemde İzmir Limanı üzerinden en çok ihracat yapılan ülkeler, sanayileşmiş Batılı ülkelerdi. ${ }^{13}$ İzmir Limanı üzerinden yapılan ihracatın değeri ise 1929-1933 yılları boyunca sürekli azaldı. Bunda, yukarıda da belirtildiği üzere tarımsal ürün fiyatlarında ya-

\footnotetext{
${ }^{13} 1929$ yılı itibariyle İzmir Limanı üzerinden miktar açısından en çok ihracat yapılan dört ülke sırasıyla Almanya (35.747.933 kg), İngiltere (31.702.365 kg), İtalya (30.399.152) ve ABD (29.460.576 kg) idi (T.C. İzmir Ticaret ve Sanayi Odası Mecmuası, Haziran 1930: 341).
} 
şanan düşüşün etkili olduğu söylenebilir. Zira bu dönemde İzmir Limanı'nın en önemli ihracat ürünleri, tarımsal ürünlerden oluşuyordu. ${ }^{14}$ Dolayısıyla bu ürünlerin fiyatlarında yaşanan düşüş, İzmir Limanı aracılığıyla yapılan ihracatın değerini de olumsuz etkiledi. Örneğin tütünün İzmir Limanı ihracatındaki payı, değer bakımından, 1929 yılında \%32,2 oranındaydı. İzmir Limanı'ndaki bir başka önemli ihracat ürünü üzümün ise 1929 yılındaki payı \%21,5 idi. Ayrıca incirin 1929 yılındaki ihracattaki payı \%10'du. İzmir Limanı'ndan ihraç edilen bu üç önemli tarım ürünün fiyatları ise Tablo 1'de görüldügü gibi, Büyük Buhran yıllarında hızla düştü. Bu da İzmir Limanı üzerinden yapılan ihracatı değer bakımından azalttı. Görüldüğü üzere, İzmir Limanı'ndaki ihracatın azalmasının arka planında bir dış sebep olarak 1929 Dünya Ekonomik Krizi bulunuyordu. Öte yandan limandaki ihracat faaliyetlerinde yaşanan düşüşte bazı iç etkenlerin de varlığı söz konusuydu. Bu iç etkenler, limanı yöneten Fransız sermayeli İzmir Rıhtımı Anonim Şirketi ve Türk sermayeli İzmir Liman ve Körfez Şirketi ile ilgili problemlerden kaynaklanıyordu.

\section{Büyük Buhran döneminde İzmir Limanı'nı yöneten şirketler ile ilgili sorunlar}

Çalışmanın birinci bölümünde bahsedildiği üzere, İzmir Limanı'ndaki rıhtımı yöneten İzmir Rıhtımı Anonim Şirketi, 1867'de İngilizler tarafından kurulmuş ve aynı yıl İzmir Limanı'nda rıhtım işletme imtiyazına sahip olmuştu. Ancak şirket daha sonra 1869 yılında Fransızların eline geçmişti. Ardından şirketin imtiyaz süresi, 1891 yılında Osmanlı Hükümeti ile şirket arasında yapılan anlaşmayla 31 Aralık 1952 tarihine kadar uzatılmıştı. Anlaşmaya göre şirket, 1 Ocak 1913 tarihinden sonra hükümet tarafından satın alınabilecekti. Ayrıca şirket, rıhtım vergisinden elde ettiği gelirlerin \%50'sini devlete vermekle sorumluydu. ${ }^{15}$

Büyük Buhran yıllarına gelindiğinde, ekonomik krizin İzmir Limanı üzerindeki etkilerinden bir tanesi, İzmir Limanı üzerinden yapılan ihracatın azalması olmuştu. İhracatın azalmasında 1929 Krizi'nin yanı sıra İzmir Rıhtımı Anonim Şirketinin uyguladığı rıhtım vergisinin de etkili olduğunu söylemek mümkündür. Zira bu vergi, liman üzerinden ihracat yapan tüccarın maliyetini yükseltmekteydi. Öte yandan 1929-1930 yılları arasında İzmir Limanı'ndaki ihracatta yaşanan hızlı düşüşün, hükümetin dikkatini çektiği düşünülebilir. Zira İzmir Limanı ülkenin en önemli ihracat merkezlerinden biriydi. Ayrıca İzmir Rıhtımı Anonim Şirketinin hükümet tarafından satın alınacağına dair haberler 1930 yılı sonlarında İzmir' in yerel basınına yansımaya başlamıştı.

\footnotetext{
${ }^{14} 1929$ yılı itibariyle İzmir Limanı aracıllğ̆ıla miktar bakımından en çok ihraç edilen dört ürün sırasıyla Üzüm (42.154.339 kg), Palamut (36.257.449 kg), İncir (23.838.700 kg) ve Tütün (18.922.830 kg) idi (T.C. İzmir Ticaret ve Sanayi Odası Mecmuası, Haziran 1930: 337).

${ }^{15}$ İzmir Rıhtımı Anonim Şirketinin İzmir Limanı'nda uyguladığ 1 rıhtım vergisi $\% 0,05$ oranındaydı (Kurt, 2012: 120).
} 
30 Aralık 1930'da İzmir'in yerel gazetelerinden Hizmet gazetesinde ${ }^{16}$ yer alan bir haberde, hükümetin Fransız şirketi satın almaya karar verdiği bilgisi yer almıştı. Haberde ayrıca, şirketin rıhtım vergisi meselesinde oldukça "kıskanç ve tamahkâr" olduğu belirtilmişti. Fransız şirket, almakta olduğu rıhtım vergisi nedeniyle ihracat mallarının maliyetini yükseltmekten sorumlu tutulmuştu (Hizmet, 30 Aralık 1930). Görüldügüu üzere, İzmir Rıhtımı Anonim Şirketi, İzmir Limanı üzerinden yapılan ihracata zarar verdiği için tepki çekmekteydi.

İzmir Rıhtımı Anonim Şirketi ile ilgili rıhtım vergisi meselesinden daha büyük bir sorun ise, 1931 yılı sonlarında ortaya çıkmıştı. 22 Aralık 1931'de şirkete ait defterlerde, Maliye Vekâleti tarafından incelemeler yapılmaya başlanmıştı (Cumhuriyet, 23 Aralık 1931). Yapılan incelemelerde, şirketin rıhtım vergisi gelirlerinden devlete vermesi gereken payı ödemediği anlaşılmıştı. Şirketin devlete ödemekle yükümlü olduğu pay ise 850.000 TL olarak tespit edilmişti. Bunun üzerine 9 Ocak 1932 tarihinde toplanan Bakanlar Kurulu, şirkete el konulması kararını vermişti (BCA, 30.18.1.2.25.3.10). Bakanlar Kurulu'nun kararı üzerine 10 Ocak 1932'de İzmir Rıhtımı Anonim Şirketine el konuldu (Resmî Gazete, 25 Haziran 1933). El konma işlemi İzmir Valisi Kâzım Paşa'nın başkanlığını yaptığı bir heyet ve polis tarafından yapıldı. İzmir Rıhtımı Anonim Şirketi müdürlüğüne, aynı zamanda İzmir Liman ve Körfez Şirketi müdürü olan Dr. Hulusi Bey getirildi (Cumhuriyet, 12 Ocak 1932). Bu noktada söylenebilir ki, Hulusi Bey'in Fransı şirketin müdürlüğüne getirilmesi üzerine, İzmir Limanı fiili olarak tek bir elden yönetilmeye başlandı. Limanın resmen tek çatı altından yönetilmesi ise çalışmanın devamında ele alınacağı üzere 1934 yılında gerçekleşecekti.

İzmir Rıhtımı Anonim Şirketi defterlerinde yapılan ilk incelemelerde şirketin devlete rıhtım vergisi gelirleri içerisinden vermesi gereken pay 850.000 TL olarak tespit edilmişti. Ancak şirkete el konulmasının ardından devam eden incelemelerde, bu miktarın 1.200.000 TL olduğu anlaşılmıştı (BCA, 230.0.0.0.131.20.3). ${ }^{17}$ Ayrıca şirketin, bu yolsuzluğu gizlemek için İzmir Nafia Komiseri Emin Bey'e rüşvet verdiği de tespit edilmişti (Hizmet, 23 Şubat 1932). İzmir Rıhtımı Anonim Şirketi yöneticilerinin yolsuzluk ve rüşvet suçlamalarıyla yargılandıkları dava 29 Mart 1932 tarihinde başlamıştı (Anadolu, ${ }^{18}$ 30 Mart 1932). Haklarında dava açılan şirketin üst düzey yetkilileri arasında Şirket Müdürü Mösyö Iv Gifre, şirket muhasebecisi Mösyö Pere ve şirketin eski delegelerinden Mösyö Jordan vardı. Fransız şirketin yetkililerine, şirket gelirlerinin olduğundan daha az gösterilmesi ve bazı evrakların yakılarak imha edilmesi suçlamaları yöneltilmişti (Elmac1, 2017: 799-800). Fransız şirket

\footnotetext{
${ }^{16}$ Hizmet gazetesi, İzmir'in yerel gazetelerinden biridir. İlk sayısı 1886 yılında Halid Ziya Bey (Uşakl1gil) ve Tevfik Nevzad tarafından çıkarılmıştır (Arıkan, 1985: 105).

${ }^{17}$ Konuyla ilgili arşiv belgesi Ek-2'de verilmiştir.

${ }^{18}$ Anadolu gazetesi, İzmir'in yerel gazetelerinden biridir. Gazete yayın hayatına 1911 yılında İttihat ve Terakki'nin İttihat adlı gazetesinin devamı olarak başlamıştı (Arıkan, 1985: 109).
} 
aleyhine açlan davanın sonuçlanması 1932 yılının ağustos ayında gerçekleşmişti. 2 Ağustos 1932'de açıklanan iddianamede, Emin Bey'in şirketten 75.000 TL kadar rüşvet aldığı açıklanmıştı. Ayrıca şirkete ait birçok evrakın yakılması nedeniyle bu rüşvet miktarının daha fazla olabileceği de belirtilmişti (Hizmet, 3 Ağustos 1932). İzmir Rıhtımı Anonim Şirketi yetkililerinden Mösyö Iv Gifre ve Mösyö Jordan rüşvet, sahtekârlık ve evrak imha etme suçlarından bir yıl üç ay dört gün, Mösyö Pere ise sahtekârlık ve evrak imha etme suçlarından bir yıl iki ay hapis cezasına çarptırılmıştı (Hizmet, 30 Ağustos 1932). Rüşvet almakla suçlanan Emin Bey ise İsviçre'ye gittiği için mahkemeye çıkarılamamıştı ancak dava sonuçlanınca İsviçre'de tutuklanmıştı. Ardından hapishanedeyken intihar etmişti. Diğer yandan şirket yetkilileri dava sonuçlandıktan sonra temyiz mahkemesine başvurmuşlardı ve Iv Gifre kefaletle serbest kalmıştı. Ayrıca gazetelere yansıyan haberlere göre Iv Gifre yurtdışına gitmişti. Daha sonra şirket yetkilileri 1933 yılında çıkarılan genel aftan yararlanmışlardı (Elmacı, 2017: 823-825).

Fransız sermayeli İzmir Rıhtımı Anonim Şirketi ile ilgili yolsuzluk davası bu şekilde sonuçlanmıştı. Öte yandan hükümet, 1932 yılında dava devam ederken Fransız şirketi satın almak için harekete geçmişti. Fakat bu satın alma sürecine değinmeden önce Türk sermayeli İzmir Liman ve Körfez Şirketi ile ilgili yükleme-boşaltma tarifeleri sorununu ele almakta fayda vardır. Zira bu sorun, İzmir Limanı üzerinden yapılan ihracatı yakından ilgilendirmesi açısından önemliydi ve limanın devlet idaresi altına alınmasında etkili olmuştu. Çalışmanın birinci bölümünde değinildiği üzere, yönetim kurulu başkanlığını Dr. Hulusi Bey'in yaptığ 1 İzmir Liman ve Körfez Şirketi 1925 yılında kurulmuştu. Şirket, hisselerinin büyük bir çoğunluğu hükümete ait olsa da özel sektör niteliği taşımaktaydı. 1925'te hükümet tarafından şirkete İzmir Limanı'nda yükleme-boşaltma yapma ve yolcu vapuru işletme imtiyazları verilmişti. Fakat Büyük Buhran yıllarında limandaki Fransız şirketle ilgili rıhtım vergisi sorununa benzer bir problem, İzmir Liman ve Körfez Şirketi için de mevcuttu. Bu mesele, limandaki yükleme-boşaltma ücretleriydi.

1930 yılında İzmir'in yerel basınında İzmir Liman ve Körfez Şirketinin yükleme-boşaltma tarifelerinden duyulan rahatsızlık ve tarifelerde indirime gidilmesi isteği yer almaktaydı (Anadolu, 25 Nisan 1930). Gazetelerde İzmir Liman ve Körfez Şirketinin İzmir'in ihracatını koruması amacıyla kurulduğu ancak şirketin buna uygun bir şekilde faaliyet göstermemesi eleştirilmekteydi (Anadolu, 29 Nisan 1930). ${ }^{19}$ Türk şirkete yöneltilen eleştirilerde, İzmir Limanı'ndaki ticari faaliyetlerin azalmasında, dünyadaki genel ekonomik şartlar kadar limandaki yükleme-boşaltma ücretlerinin yüksek oluşunun da rol oynadığ1 söylenmekteydi (Anadolu, 30 Nisan 1930). Şirketin uyguladığı yükleme-boşaltma tarifelerine bakıldığında gazetelerdeki eleştirilerde haklılık payı

\footnotetext{
${ }^{19}$ Anadolu gazetesinin bu haberinde yer alan İzmir Liman ve Körfez Şirketini eleştiren karikatür Ek3'te verilmiştir.
} 
olduğu görülmektedir. 1925'ten önce limandaki yükleme-boşaltma ücretleri ihracatta ton başına 60-80 kuruş arasında değişmekteydi. Fakat ihracata yarar sağlanması için bu ücretlerin düşürülmesi gerekirken 1930 yılına gelindiğinde ücretler yükselmişti. Mayıs 1930 itibariyle ihracattan alınan ton başına yükleme-boşaltma ücreti 70-150 kuruş arasında değişmekteydi. Örneğin, Ege Bölgesi'nin en önemli ihracat ürünlerinden üzüm ve incirden ton başına alınan yükleme-boşaltma ücreti, 1925 öncesinde 60 kuruşken Mayıs 1930'da 70 kuruşa yükselmişti (Anadolu, 1 Mayıs 1930). Tarifelerdeki yükseliş sonraki yıllarda da devam etmiş ve üzüm ile incirden alınan ton başına yükleme-boşaltma ücreti 1933' te 75 kuruşa çıkarılmıştı (Yeni Asır, 9 Eylül 1933). ${ }^{20}$

Bu noktada belirtmekte fayda var ki, farklı yıllar arasında fiyat karşılaştırması yaparken yıllık enflasyon oranlarının da göz önünde bulundurulması gerekmektedir. Cumhuriyet'in ilk yıllarına bakıldığında, emisyon hacmi ${ }^{21}$ (dolaşımdaki para miktarı), 1925'te 165 milyon TL iken bu rakam 1930'da 163 milyon TL ve 1933'te 161 milyon TL olmuştu. Dolayısıyla 1925-1933 yılları arasında para arzında büyük bir değişiklik yaşanmamıştı. Bu para politikası ise, bir enflasyon yaşanmasının aksine deflasyon ${ }^{22}$ ortaya çıkarmıştı. Fiyatlar genel düzeyi, 1923-1930 arasında \%4 oranında, 1930-1938 y1llarında ise \%2 oranında azalmıştı (Bahar, 2004: 161-162). Görüldüğ̈̈̈ gibi, Türkiye'de 1920'li ve 1930’lu yıllarda genel fiyatlar düşüş eğiliminde olmasına rağmen, İzmir Liman ve Körfez Şirketi, limandaki yükleme-boşaltma tarifelerini yükseltmeye devam etmekteydi. 1930 ve 1933 yıllarına ait enflasyon rakamlarına ulaşılamadı̆̆ı için, bu yıllar arasında yükleme-boşaltma ücretlerinde yaşanan reel artış oranı hesaplanamamaktadır. Fakat 1930-1933 yılları arasında üzüm ve incirden ton başına alınan ücretin 70 kuruştan 75 kuruşa yükseldiği bilinmektedir. Dolayısıyla yükleme-boşaltma ücretlerinin cari olarak $\% 7,1$ oranında arttığ1 görülmektedir. Deflasyonun yaşandığı bir dönemde cari fiyatlardaki bu artıştan yola çıkılarak, limandaki yükleme-boşaltma ücretlerindeki reel artışın \%7,1'den daha fazla bir oranda gerçekleştiğini söylemek yanlış olmayacaktır.

Yüksek seviyedeki yükleme-boşaltma ücretleri, İzmir Limanı üzerinden yapılan ihracatı olumsuz etkilemekteydi. Tüccarlar İzmir Limanı'ndaki yüksek tarifeler nedeniyle, Ege Bölgesi ile benzer ürünlerin yetiştiği Yunanistan’a yönelmekteydiler. Örneğin, Manisa'nın üzümleri İzmir Limanı, Yunanistan'ın Korinth ilinde yetişen üzümler ise Pire Limanı üzerinden dünyaya ihraç edilmekteydi. Dolayısıyla tüccarların Batı Anadolu ürünlerine yönelmeleri için

\footnotetext{
${ }^{20}$ Yeni Asır gazetesi, İzmir' in yerel gazetelerinden biridir. Gazete ilk olarak 1895 yılında Asır adı altında Selanik'te yayımlanmaya başlamıştı. Daha sonra 1908 yılından itibaren Yeni Asır adını alan gazete 1924 yılında İzmir'e taşınmıştı (Çakırbaş, 2015: 17).

${ }^{21}$ Emisyon hacmi, ülkede dolaşım halinde olan toplam kâğıt para miktarıdır (İktisat Terimleri Çalışma Grubu, 2011: 83).

${ }^{22}$ Deflasyon, fiyatlar genel düzeyinin sürekli düşmesi anlamına gelmektedir. Enflasyonun (fiyatların sürekli artması durumu) tam tersidir (İktisat Terimleri Çalışma Grubu, 2011: 92, 140).
} 
İzmir Limanı'ndaki yükleme-boşaltma tarifelerinin Pire Limanı'na yakın olması gerekmekteydi. Ancak İzmir Limanı'nda 70-150 kuruş arasında değişen yükleme-boşaltma ücretlerine karşılık Pire Limanı'ndaki yükleme-boşaltma ücretleri 22,5 kuruş civarındaydı (Anadolu, 29 Mayıs 1930).

Çalışmada daha önce bahsedildiği üzere İzmir Liman ve Körfez Şirketi, limanda yükleme-boşaltma faaliyetlerinin yanı sıra vapurla yolcu taşınmasından da sorumluydu. Şirket, tarifelerle ilgili eleştirilere, yolcu vapurlarının zarar etmekte olduğu ve bu zararın yükleme-boşaltma ücretlerinden elde edilen gelirlerle kapatıldığ 1 şeklinde cevap vermekteydi (Anadolu, 29 Mayıs 1930). Büyük Buhran yıllarında Türk şirketin yolcu vapuru faaliyetlerinden zararı 1929 'da 58.445 TL, 1930 'da 49.000 TL, 1931'de 63.776 TL ve 1932 'de 63.706 TL idi (Kurt, 2012: 228-229). Ayrıca İzmir Liman ve Körfez Şirketinin yükleme-boşaltma ücretlerini yüksek tutmasında, Büyük Buhran nedeniyle yükleme-boşaltma gelirlerinin de azalmasının rol oynadığı söylenebilir. Zira ekonomik krizin etkisiyle İzmir Limanı'ndaki ticari faaliyetler hızlı bir şekilde azalmıştı.

İzmir Liman ve Körfez Şirketinin gelir ve giderleri incelendiğinde, ekonomik krizin başladığ 1929 yılından sonra şirketin gelirlerinde sürekli bir düşüş yaşandığı görülmektedir. Yıllık gelir 1929'da $301.861 \mathrm{TL}, 1930$ 'da $285.430 \mathrm{TL}$, 1931 'de 277.058 TL, 1932'de 263.886 TL, 1933'te 213.540 TL ve 1934 'te 179.383 TL idi. Büyük Buhran yıllarında şirketin gelirleri düşmüştü fakat diğer yandan şirketin çalışan ücretleri ve toplam masraflarında da azalma gerçekleşmişti. Şirket çalışanlarına ödenen toplam ücret 1928'de 97.970 TL, 1929'da 95.539 TL, 1930 'da 95.736 TL, 1931'de 89.363 TL, 1932'de 86.450 TL, 1933'te 79.344 TL ve 1934 'te 56.427 TL idi. Yaşanan bu düşüşste, çalışan sayısının azaltılması etkili olmuştu. 1928-1932 yılları boyunca şirkette 166 çalışan vardı. Fakat bu sayı 1933 'te 120 'ye ve 1934 'te 100 'e düşürülmüştü. Ayrica toplam masraflar 1928'de 211.948 TL, 1929'da 148.639 TL, 1930'da 157.517 TL, 1931'de 149.549 TL, 1932'de 225.446 TL, 1933'te 135.833 TL ve 1934'te 113.688 TL idi (T.C. İzmir Vilayeti İstatistik Yıllığı 1933-1934: 101). Türk şirketin yıllık giderlerinde yaşanan değişimlerde, şirketin sorumluluğu altında olan vapurların genel bakımlarının rol oynadığ1 söylenebilir. Örneğin giderlerin yüksek olduğu 1932'de Çankaya Vapuru' na geniş çaplı bir bakım yapılmış ve vapurun yolcu taşıma kapasitesi yükseltilmişti (Kurt, 2012: 214). İzmir Liman ve Körfez Şirketinin Büyük Buhran dönemindeki yıllık kârı ise, gelir ve gider rakamları karşılaştırıldığında görüleceği üzere, 1928 'de $126.136 \mathrm{TL}, 1929$ 'da 153.222 TL, 1930'da $127.913 \mathrm{TL}$, 1931'de 127.509 TL, 1932'de 38.440 TL, 1933'te 77.707 TL ve 1934'te 65.695 TL idi. Görüldügü gibi, Büyük Buhran yıllarında şirketin yıllık kârında düşüş yaşanmıştı. Bu durumun şirketi, yükleme-boşaltma tarifelerini yüksek tutmaya yönlendirdiği düşünülebilir. Ancak her ne kadar şirketin yıllık kârı azalsa da şirket, ekonomik krize rağmen kâr etmeye devam etmekteydi. 
Büyük Buhran yıllarında yüksek tutulan yükleme-boşaltma tarifelerinin, liman üzerinden ihracat yapan tüccara ve dolaylı olarak Ege Bölgesi'nde ihracata yönelik üretim yapan çiftçi ailelerine olumsuz yansıdığını söylemek mümkündür. İzmir Liman ve Körfez Şirketi ile ilgili bu sorunun, İzmir Limanı'nın devlet idaresi altına alınmasında rol oynadığı söylenebilir. Zira ortada, kamu yararını zedeleyen bir durum söz konusuydu ve aşağıda ele alınacağı üzere kamu yararının sağlanması hükümet için oldukça önemliydi.

\section{İzmir Limanı'nın devlet idaresi altına alınması}

Çalışmanın üçüncü bölümünde ele alındığı üzere, Fransız sermayeli İzmir Rıhtımı Anonim Şirketinin defterlerinde Aralık 1931 ve Ocak 1932'de yapılan incelemelerde, şirketin hükümete rıhtım vergisi gelirlerinden vermesi gereken payı ödemediği anlaşılmıştı. Bunun üzerine Ocak 1932'de şirkete el konulmuş ve şirketin müdürlügüne, aynı zamanda Türk sermayeli İzmir Liman ve Körfez Şirketi müdürü olan, Dr. Hulusi Bey getirilmişti. Böylece hükümetin İzmir Limanı'nı devlet idaresi altına alma süreci resmen başlamıştı.

Fransız şirkete el konulması sonrasında, hükümetin yabancı sermayeye karşı olduğuna dair iddialar ortaya atılmıştı. Bunun üzerine Nafia Vekâleti konuyla ilgili bir açıklama yapma gereği duymuştu. Bakanlığın açıklamasına göre, ülkede bir yabancı sermaye karşıtlığı bulunmamaktaydı ve kimi durumlarda yabancı şirketlere gereğinden fazla hoşgörü gösterilmekteydi. Ĕ̆er yabanc1 şirketler imtiyaz sözleşmelerine aykırı hareket ederlerse, hükümet buna kayıtsiz kalamazdı (Elmac1, 2017: 815-816). Ulusal gazetelere yansiyan haberlerde de "temiz ve samimi sermayeler başın tacıdır" ifadeleri kullanılmış ve hukuka uygun bir şekilde faaliyet gösteren yabancı şirketlere karşı olunmadığı söylenmişti (Cumhuriyet, 17 Ocak 1932). Bu noktada belirtmekte fayda var ki, hükümet yabancı şirketleri satın alırken önceliği demiryolu, liman, elektrik, su ve havagazı gibi kamu yararını yakından ilgilendiren alanlara vermekteydi. Daha sonraları 1938'de, Celal Bayar yapmış olduğu bir konuşmada, yabancı sermayeye karşı olmadıklarını vurgulamış ve millileştirilen şirketlerin imtiyaz sözleşmelerine uymadıklarını söylemişti (Sükan, 2014: 220).

Bu arada İzmir'deki yerel basında, rıhtımın İzmir Belediyesi'ne devredilmesi gerektiğine yönelik haberler çıkıyordu. Hatta gazetelere göre rıhtımın yanı sıra, İzmir Liman ve Körfez Şirketi de belediyeye devredilmeli ve yükleme-boşaltma işleriyle belediye ilgilenmeliydi. Bunun nedeni olarak ise, liman işlerinin tek bir elden yönetilmesi gerekliliği öne sürülüyordu (Hizmet, 29 Ocak 1932). İzmir Liman ve Körfez Şirketi de limanın tek bir çatı altından idare edilmesini savunuyor ancak şirket bunun, rıhtımın kendisine devredilmesi suretiyle gerçekleşmesini istiyordu (Hizmet, 26 Şubat 1932). Rıhtımın İzmir Liman ve Körfez Şirketine mi yoksa İzmir Belediyesi'ne mi devredileceği tartışmala- 
r1 ve rıhtım davası devam ederken, hükümet Fransız şirketi satın almak için harekete geçti. Nafia Vekâleti ile İzmir Rıhtımı Anonim Şirketi arasındaki ilk görüşmeler 7 Mayıs 1932'de başladı (Cumhuriyet, 8 Mayıs 1932). Görüşmeler Temmuz 1932'ye kadar devam etti ve sonunda hükümet rihtımı satın almaya karar verdi (Hizmet, 29 Temmuz 1932). 3 Ekim 1932 tarihinde ise Nafia Vekâleti ile İzmir Rıhtımı Anonim Şirketi arasında şirketin hükümet tarafından satın alınmasına dair bir sözleşme parafe edildi (Gürsoy, 2013: 197).

İzmir Limanı'ndaki rıhtımın devredilmesi meselesiyle ilgili olarak Mart 1933'te İktisat Vekâleti tarafından yapılan açıklamada, limanın ticari açıdan önemli olması sebebiyle devlet idaresi altına alınması gerektiği belirtildi (Yeni Asır, 27 Mart 1933). Ayrıca Maliye Vekâleti de İzmir Limanı'nın hükümete bağlı bir idare aracılığıyla yönetilmesi gerektiğine dair raporunu Mayıs 1933'te TBMM Başkanlığı'na sundu (TBMM Zabıt Ceridesi, 18 Haziran 1934: TBMM Komisyon Raporu Sıra No 235). Maliye Vekâletinin raporunda, liman faaliyetlerinin kamu hizmeti gördüğü ve bu nedenden dolayı İzmir Limanı'nın özel bir şirket yerine bizzat devlet tarafından idare edilmesi gerektiği açılandı. Zira özel şirketler ticari kaygılarla hareket ederken, bir devlet işletmesi limanda kâr amacı gütmeden faaliyet gösterebilirdi. Bu da kamu yararının sağlanması için gerekliydi. Dolayısıyla İzmir Limanı, devlet tarafından yönetilmeliydi (TBMM Zabıt Ceridesi, 18 Haziran 1934: TBMM Komisyon Raporu Sıra No 235). Bu noktada görülmektedir ki, hükümet, sadece İzmir Limanı'ndaki rıhtımın değil, İzmir Limanı'nın bir bütün olarak devlet idaresi altına alınması gerektiğini düşünüyordu. Dolayısıyla hükümetin bu görüşleri, sadece Fransız sermayeli İzmir Rıhtımı Anonim Şirketini değil, özel bir şirket niteliği taşıyan Türk sermayeli İzmir Liman ve Körfez Şirketini de yakından ilgilendiriyordu.

Maliye Vekâletinin raporundan sonra TBMM konuyla ilgili çalışmalarına başladı ve 12 Haziran 1933'te "İzmir Rıhtım Şirketinin İmtiyazı ile Tesisatının Satın Alınmasına Dair Kanun" meclisten geçti. Kanun ile, Nafia Vekâletine, yukarıda ele alınan, 3 Ekim 1932 tarihli sözleşmeyi imzalama yetkisi verildi. Kanuna göre hükümet, İzmir Limanı'ndaki rıhtımın imtiyaz ve mülkiyet haklarını İzmir Liman ve Körfez Şirketine devredebilecekti (TBMM Kanunlar Dergisi, 12 Haziran 1933: 1019-1024). 12 Haziran 1933'te meclisten geçen "İzmir Rıhtım Şirketinin İmtiyazı ile Tesisatının Satın Alınmasına Dair Kanun", 25 Haziran 1933'te Resmî Gazete'de yayımlanarak yürürlüğe girdi ve Nafia Vekâleti ile İzmir Rıhtımı Anonim Şirketi arasında satın alma sözleşmesi imzalandı. Hükümetin satın almayla ilgili hukuki dayanağı, 18 Mayıs 1891 tarihinde şirket ile Osmanlı Hükümeti arasında imzalanmış olan imtiyaz anlaşmasıydı (TBMM Kanunlar Dergisi, 12 Haziran 1933: 1019-1024). ${ }^{23}$ Hükümet ile İzmir Rıhtımı

\footnotetext{
${ }^{23}$ Osmanlı Hükümeti ile İzmir Rıhtımı Anonim Şirketi arasında imzalanmış olan 1891 tarihli sözleşmenin 12. maddesine göre, devlet 1 Ocak 1913 tarihinden sonra şirkete ait rihtım, bina ve arazileri satın alabilecekti (Kütükoğlu, 2000b: 234).
} 
Anonim Şirketi arasında yapılan satın alma sözleşmesine göre şirketin İzmir Limanı'ndaki arsa ve binaları devlet mülkiyetine geçecekti. Bu satın alma karşıl1ğında yapılacak ödeme, dört taksit halinde ödenecek 1.950 .000 frank, 21 takside bölünen 5.718.636 frank ve tek seferde ödenecek 158.844 frank olarak, toplamda 7.827.480 frank şeklinde kabul edildi (Resmî Gazete, 25 Haziran 1933).

Yukarıda değinildiği üzere hükümet, İzmir Limanı'ndaki rıhtımı İzmir Liman ve Körfez Şirketine devretme hakkına sahipti. Hükümet bu hakkını 15 Şubat 1934 tarihinde kullandı ve karar 28 Şubat 1934'te “İzmir Rıhtım Tesisatının İzmir Liman ve Körfez Şirketine Devrine Ait Talimatname” adı altında Resmî Gazete'de yayımlandı (Kütükoğlu, 2000b: 237). Böylece rıhtımın yönetimi İzmir Liman ve Körfez Şirketine devredildi. Talimatnamede bu devir işleminden sonra İzmir Limanı'nda uygulanacak olan gümrük tarifeleri de yer alıyordu. Bu tarifelere göre, ithalattan mal değerinin \%1'i oranında rıhtım vergisi alınacak fakat ihraç edilen ürünlerden rıhtım vergisi alınmayacaktı (Resmî Gazete, 28 Şubat 1934). Bu noktada görülmektedir ki, Büyük Buhran yıllarında İzmir Limanı üzerinden yapılan ihracatı olumsuz etkileyen hususlardan biri olan ihracat mallarından rıhtım vergisi alınması, rıhtımın İzmir Liman ve Körfez Şirketine devredilmesi ile son buldu. Bu da kamu yararının sağlanması ve bölgenin ekonomisi için önemli bir gelişmeydi. Zira ihracattan alınan rıhtım vergisinin kaldırılması ile ihracatçı tüccarın ve üreticinin maliyeti azalacaktı.

İzmir Limanı'ndaki rıhtımın İzmir Liman ve Körfez Şirketine devredilmesi ile, limandaki yükleme-boşaltma, yolcu taşımacılığ 1 ve rıhtımın yönetimi faaliyetleri resmen tek çatı altında toplanmıştı. Böylece limandaki önemli bir sorun çözüme kavuşmuştu. Fakat hükümetin İzmir Limanı ile ilgili planı henüz bitmemişti. Sırada, limanın bütünüyle ve doğrudan hükümete bağlı bir idare altına alınması vardı. Maliye Vekâletinin konuyla ilgili raporunda açıkça görüldüğü üzere, hükümetin görüşü, limanın kamu hizmeti görmesi nedeniyle özel bir şirket tarafından yönetilmemesi gerektiği yönündeydi. İzmir Liman ve Körfez Şirketi de her ne kadar Türk sermayeli olsa da özel şirket niteliği taşımaktaydı ve limanı, kâr amacı güderek yönetmekteydi. Bu da şirketin uyguladığı yükleme-boşaltma tarifelerinin yüksek oluşunda görülmektedir. Ayrıca şirket, İzmir ticaretine zarar verdiği gerekçesiyle İzmir basını tarafından eleştirilmekteydi. Dolayısıyla limanda, kamu yararını zedeleyen bir durum söz konusuydu.

İzmir Liman ve Körfez Şirketinin tasfiye edilerek limanın devlet idaresi altına alınması için hazırlanan "Liman İşlerinin Hükümetçe İdaresine Dair Kanun", 18 Haziran 1934 tarihinde TBMM'de kabul edildi ve yürürlüğe girmesi 25 Haziran 1934'te Resmî Gazete'de yayımlanmasıyla gerçekleşti (TBMM Kanunlar Dergisi, 18 Haziran 1934: 852). Kanunun mecliste görüşülmesi esnasında Maliye Vekili Fuat Bey (Ağralı), limanın hükümet idaresi altına alınmasının gerekçesi olarak, liman işlerinin bir kamu hizmeti niteliği taşımasını göstermiş- 
ti. Fuat Bey ayrıca, kanun ile İstanbul Liman Şirketinin de tasfiye edileceğini açıklamıştı (TBMM Zabıt Ceridesi, 18 Haziran 1934: 212). İzmir Limanı'nı ve İstanbul Limanı'nı yönetecek idarelerin kurulması, hükümet tarafından kabul edilen 27 Aralık 1934 tarihli "İstanbul ve İzmir Liman İşleri Müdürlüklerinin Vazifelerine ve Bunların Murakabesine Dair Kararname" ile gerçekleşti. Kararname Resmî Gazete'de 5 Ocak 1935'te yayımlandı. Kararname ile İzmir Limanı'nın yönetimi İzmir Liman İşleri Umum Müdürlügüne, İstanbul Limanı'nın yönetimi ise İstanbul Liman İşleri Umum Müdürlüğüne verildi. Her iki idare de Maliye Vekâletine bağlı olacaklardı (Resmî Gazete, 5 Ocak 1935). İzmir Liman İşleri Umum Müdürlüğünün yönetimine Dr. Hulusi Bey tayin edildi (BCA, 30.11.1.0.92.44.14). İdareye yükleme-boşaltma işlerini yapma, rıhtım vergisi toplama, rıhtımdaki atlı tramvayı işletme ve İzmir Limanı'nda yolcu taşıma hakları verildi (Resmî Gazete, 5 Ocak 1935). Böylece, 1932 yılının başında Fransız sermayeli İzmir Rıhtımı Anonim Şirketine el konulmasıyla başlayan İzmir Limanı'nın bütünüyle devlet idaresi altına alınması süreci resmen tamamlandı. İzmir Limanı, 5 Ocak 1935'ten itibaren Maliye Vekâletine bağlı İzmir Liman İşleri Umum Müdürlüğü tarafından yönetilmeye başlandı.

\section{Sonuç}

Bu çalışma ile, Büyük Buhran yıllarında İzmir Limanı'nın hukuki durumunda yaşanan değişimler neden-sonuç ilişkisi çerçevesinde değerlendirilmeye çalışılmıştır. Araştırma ile ulaşılan sonuçlardan biri, Büyük Buhran'ın, İzmir Limanı'nın devlet idaresi altına alınmasında rol oynadığı yönündedir. Şöyle ki, ekonomik krizin dünyadaki ve Türkiye'deki etkilerinden biri, dış ticaret hacimlerinin azalması olmuştu. Bu da bir ihracat merkezi olan İzmir Limanı'na olumsuz yansımıştı. Çalışmanın ikinci bölümünde bahsedildiği üzere, limandaki ihracat 1929-1931 yılları arasında değer olarak 80.853.923 TL'den 43.268.584 TL'ye, miktar olarak ise 193.285 .622 kg'den 158.886 .075 kg'ye gerilemişti. İzmir Limanı üzerinden yapılan ihracatta yaşanan düşüş, ülke ekonomisine de zarar vermekteydi. Dolayısiyla limandaki ihracat faaliyetlerini olumsuz etkileyen sorunların çözüme kavuşturulması gerekmekteydi. Bu noktada belirtmekte fayda var ki, İzmir' in yerel basınında, hükümetin İzmir Limanı'nı millileştirmeye karar vermesi ile ilgili haberler 1930 yılının sonlarında çıkmaya başlamıştı. Hükümetin resmen harekete geçmesi ise Ocak 1932'de gerçekleşmişti. Dolayısıyla Büyük Buhran'ın dış ticareti olumsuz etkilemesi üzerine, hükümetin limanı millileştirmek için harekete geçmiş olduğu düşünülebilir.

Çalışma ile ulaşılan bir diğer sonuç, İzmir Limanı'nın devlet idaresi altına alınmasında, Fransız sermayeli İzmir Rıhtımı Anonim Şirketinin ve Türk sermayeli İzmir Liman ve Körfez Şirketinin limandaki ihracat faaliyetlerine zarar veren uygulamalarının etkili olduğu yönündedir. Fransız şirket, limandaki rıhtımın yönetiminden sorumluydu ve ihracattan rihtım vergisi toplamaktaydı. Türk 
şirket ise, yüksek miktarda yükleme-boşaltma ücreti almaktaydı. Her iki şirket de aldıkları bu ücretler nedeniyle yerel basın tarafından eleştirilmekteydiler. Zira ihracattan rıhtım vergisi alınması ve yükleme-boşaltma ücretlerinin yüksek oluşu, İzmir Limanı üzerinden ihracat yapan tüccarın maliyetini yükseltmekteydi. Bu da önemli bir ihracat bölgesi olan ve İzmir Limanı üzerinden dünyaya açılan Ege Bölgesi'nin ve dolayısıyla Türkiye'nin ekonomisini olumsuz etkilemekteydi. Ayrıca Fransız şirket ile ilgili yolsuzluk problemi de mevcuttu. Şirket rıhtım gelirlerini az göstermek suretiyle bu gelirlerden devlete vermesi gereken payı da azaltmıştı. Bu da ülke ekonomisi aleyhinde önemli bir sorun teşkil etmiş ve İzmir Limanı'nın millileştirilmesi sürecini başlatan olay olmuştu.

İzmir Limanı'nın yönetimiyle ilgili tüm bu sorunlar, kamu yararını zedeleyen bir durum ortaya çıkarmaktaydı. Hükümetin de kamu yararını sağlayabilmek için İzmir Limanı'nın hukuki durumuna müdahale ettiğini söylemek mümkündür. Zira İktisat Vekâleti ve Maliye Vekâleti, İzmir Limanı'nın özel bir şirket yerine bir devlet idaresi tarafından yönetilmesi görüşüne sahiptiler. Buna gerekçe olarak ise, özel bir şirketin kâr amacı güderek çalışacağını ve kamu yararını gözetmeyeceğini göstermişlerdi. Öte yandan bir devlet idaresi, İzmir Limanı'nı kâr amacı gütmeden ve kamu yararını gözeterek yönetebilirdi. Dolayısıyla çalışma ile ulaşılan bir diğer sonuç, İzmir Limanı'nın millileştirilmesinde kamu yararının gözetilmesi nedeninin etkili olduğu yönündedir.

Ayrıca, 1932 yılında hükümet tarafından Fransız sermayeli İzmir Rıhtımı Anonim Şirketine el konulması sonrasında Türkiye'de yabancı sermaye karşıtlı̆̆ olduğuna yönelik iddialar ortaya atılmıştı. Fakat Fransız şirkete el konulmasına yol açan olay, şirketin yolsuzluk yaptığının anlaşılması olmuştu. Ülke ekonomisine zarar veren bu duruma hükümetin kayıtsız kalmayarak müdahale etmesi oldukça doğaldı. Ayrıca, hükümet, Fransız şirkete ait olan rıhtımı satın aldıktan sonra Türk sermayeli İzmir Liman ve Körfez Şirketini de tasfiye etmişti. Dolayısıyla İzmir Limanı'nın devlet idaresi altına alınmasında yabancı sermayeye değil, özel sermayeye karşı bir tutumun olduğu anlaşılmaktadır. Zira tıpkı Fransız şirket gibi, Türk şirket de özel bir şirketti ve kâr amacı güderek çalışmaktaydı. Hükümet raporlarında vurgulandığı üzere liman yönetimi, bir çeşit kamu hizmeti olduğu için özel sermayeye bırakılmamalıydı. Dolayısıyla limanın devlet idaresi altına alınması süreci değerlendirildiğinde, İzmir Limanı'nın millileştirilmesinin bir yabancı sermaye karşıtlı̆̆ından kaynaklanmadığını söylemek mümkündür. Bu çalışma sonunda ulaşılan genel bir sonuç belirtilecek olursa, Büyük Buhran'ın İzmir Limanı'nı ticari açıdan olumsuz yönde etkilediği fakat diğer yandan limanın devlet idaresi altına alınmasında da rol oynadığı söylenebilir. Dolayısıyla 1929 Krizi'nin İzmir Limanı'na hukuki açıdan olumlu bir etkisinin olduğu görülmektedir. 


\section{Kaynakça}

(12 Ocak 1929). Anadolu ve Mersin-Tarsus-Adana Demir Yolları ve Haydar Paşa Limanı ve Zürihte Şark Demir Yolları Bankası arasında münakit dört kita itilafname ve merbutatının tasdiklerine ait kanun [1928]. Resmî Gazete.

(25 Nisan 1930). Tahmil ve tahliye. Anadolu.

(29 Nisan 1930). Liman inhisarları. Anadolu.

(30 Nisan 1930). Liman inhisarı. Anadolu.

(1 Mayıs 1930). Liman inhisar1. Anadolu.

(29 Mayıs 1930). Liman işleri meselesi. Anadolu.

(30 Aralık 1930). İzmir Rıhtımı hükümet tarafından satın alınacaktır. Hizmet.

(23 Aralık 1931). İzmir rıhtım şirketinde teftişat. Cumhuriyet.

(12 Ocak 1932). İzmir rıhtım şirketini hükümet aldı. Cumhuriyet.

(17 Ocak 1932). İzmir rıhtım şirketine niçin vaz'1yet edildi?. Cumhuriyet.

(29 Ocak 1932). Kestirme yol. Hizmet.

(23 Şubat 1932). Rıhtım şirketi. Hizmet.

(26 Şubat 1932). Liman ve rıhtım işleri. Hizmet.

(30 Mart 1932). Rıhtım suiistimali davası dün başladı. Anadolu.

(8 Mayıs 1932). İzmir rıhtım şirketi satın alınıyor. Cumhuriyet.

(29 Temmuz 1932). İzmir Rıhtımı. Hizmet.

(3 Ağustos 1932). Rıhtım davası. Hizmet.

(30 Ağustos 1932). Rihtım davası. Hizmet.

(27 Mart 1933). Rıhtım işleri. Yeni Asır.

(25 Haziran 1933). İzmir Rıhtım Şirketinin imtiyazı ile tesisatının satın alınmasına dair kanun [1933]. Resmî Gazete.

(9 Eylül 1933). Yeni Asır.

(28 Şubat 1934). İzmir rıhtım tesisatının İzmir Liman ve Körfez Şirketine devrine ait talimatname [1934]. Resmî Gazete.

(5 Ocak 1935). İstanbul ve İzmir Liman İşleri Müdürlüklerinin vazifelerine ve bunların murakabesine dair kararname [1934]. Resmî Gazete.

(14 Mart 1935). İzmir Limanı nizamnamesi hakkında kararname [1935]. Resmî Gazete.

Amadeo, K. (2020). Unemployment rate by year since 1929 compared to inflation and GDP. The Balance. 10 Ağustos 2020 tarihinde https://www.thebalance. com/unemployment-rate-by-year-3305506 adresinden erişildi. 
Aksoy, Y. (2002). Smyrna-İzmir: Efsaneden gerçeğe. İzmir Büyükşehir Belediyesi Kültür Yayını.

Arıkan, Z. (1985). Tanzimat ve Meşrutiyet dönemlerinde İzmir basını. Tanzimat'tan Cumhuriyet'e Türkiye Ansiklopedisi (c. 1, s. 103-111). İletişim Yayınları.

Atay, Ç. (1998). Osmanlı'dan Cumhuriyet'e İzmir planları. Yaşar Eğitim ve Kültür Vakfi.

Avcı, R. (2015). Sömürünün ulaşım aygıtları: Bağdat Demiryolu özelinde Alman emperyalizmi. Mukaddime, 6(2), 263-282.

Azrak, Ü. (1970). Millileştirme ve kamu hizmeti. İstanbul Üniversitesi Hukuk Fakültesi Mecmuası, 36(1-4), 44-78.

Bahar, O. (2004). Türkiye'de Atatürk Dönemi'nde (1923-1938) uygulanan para politikaları. Yönetim ve Ekonomi, 11(1), 155-166.

Baykara, T. (1974). İzmir şehri ve tarihi. Ege Üniversitesi Matbaası.

Çakırbaş, E. (2015). İzmir basınındaki yansımalarıyla Serbest Cumhuriyet Fırkası. [Yüksek lisans tezi], Aksaray Üniversitesi.

Elmac1, M. E. (2017). Ekonomik bir kurum olarak devletleştirme sürecinde İzmir Limanı ve yolsuzluk mahkemeleri. E. Ünlen (Ed.). Türkiye Cumhuriyeti'nin Ekonomik ve Sosyal Tarihi Uluslararası Sempozyumu Bildirileri (781-835). Atatürk Araştırma Merkezi Yayınları.

Eşiyok, A. (2010). Osmanlı İmparatorluğu'nun dünya ekonomisine eklemlenmesinde bir dönüm noktası: 1838 Serbest Ticaret Anlaşması. Mülkiye, 34(266), 67-108.

Goffman, D. (1995). İzmir ve Levanten dünya (1550-1650) (A. Anadol ve N. Kalaycıoğlu, Çev.). Tarih Vakfı Yurt Yayınları. (Orijinali 1990'da yayımlanmıştır).

Gözcü, A. (2013). 1929 Dünya Ekonomik Buhranı ve Türkiye. (2. Bs.). Libra Kitapçılık ve Yayıncılık.

Gürsoy, M. (2013). Tarihi, ekonomisi ve insanlarn ile bizim İmirimiz. (2. Bs.). Metis Yayıncilik.

Liman. EtimolojiTürkçe. 7 Ağustos 2020 tarihinde https://www.etimolojiturkce. com/kelime/liman adresinden erişildi.

İktisat Terimleri Çalışma Grubu (2011). İktisat terimleri sözlüğü. Türk Dil Kurumu Yayınları.

Işık, F. (2009). Anadolu-İon uygarlığı: Kolonizasyon ve Doğu Hellen kavramlarına eleştirisel bir bakış. Ankara Üniversitesi Dil ve Tarih Coğrafya Fakültesi Anadolu Dergisi, (35), 53-86. 
Işık, N. ve Duman E. (2012). Reel ve finansal göstergeler açısından 1929 Dünya Ekonomik Buhranı ve 2008 Küresel Krizi: Karşılaştırmalı bir analiz. Manisa Celal Bayar Üniversitesi İktisadi ve İdari Bilimler Fakültesi Yönetim ve Ekonomi Dergisi, 19(2), 239-260.

Karabulut, U. (2011). Ticari açıdan İzmir Limanı (1923-1929). [Yüksek lisans tezi], Dokuz Eylül Üniversitesi.

Kasaba, R. (1994). İzmir. Ç. Keyder, E. Özveren, D. Quataert (Ed.). Doğu Akdeniz'de Liman Kentleri, (1-22). Tarih Vakf1 Yurt Yayınları.

Koçak, F. (2013). II. Meşrutiyet'ten Cumhuriyet'e İmir şehrinde üretim ve diş ticaret. İzmir Büyükşehir Belediyesi Kültür Yayını.

Kurt, S. (2012). İzmir'de kamusal hizmetler 1850-1950. İzmir Büyükşehir Belediyesi Kültür Yayını.

Kurutlu, V. T. (2013). 19. yüzyılın ikinci yarısında İstanbul'da aydınlatma aracı olarak havagazı. [Yüksek lisans tezi], Gazi Üniversitesi.

Kütükoğlu, M. (2000a). XV. ve XVI. asırlarda İmir kazasının sosyal ve iktisadi yapısı. İzmir Büyükşehir Belediyesi Kültür Yayını.

Kütükoğlu, M. (2000b). İzmir tarihinden kesitler. İzmir Büyükşehir Belediyesi Kültür Yayını.

Memiş, N. (2008). 19. yüzyıl Osmanlı Imparatorluğu'nda ekonomik yapı ve dış ticaret. [Yüksek lisans tezi], Atatürk Üniversitesi.

Néré, J. (1980). 1929 Krizi (V. Toprak, Çev.). Ankara İktisadi ve Ticari İlimler Akademisi Yayınları. (Orijinali 1968'de yayımlanmıştır).

Öner, D. (2015). Deniz ticaretinde limanlar ve Türkiye uygulaması. [Yüksek lisans tezi], İstanbul Üniversitesi.

Önsoy, R. (1988). Tanzimat Dönemi Osmanlı sanayii ve sanayileşme politikası. Türkiye İş Bankası Kültür Yayınları.

Pamuk, Ş. (1988). 100 soruda Osmanlı-Türkiye iktisadi tarihi 1500-1914. Gerçek Yayınevi.

Pınar, İ. (1998). Gezginlerin gözüyle İzmir: XVII. Yüzyıl. Akademi Kitabevi.

Sükan, B. (2014). İmparatorluk'tan Cumhuriyet'e Türkiye'de yabancı sermaye anlayışı. Ankara Üniversitesi Türk Inkılap Tarihi Enstitüsü Atatürk Yolu Dergisi, 14(54), 195-222.

T.C. Başbakanlık İstatistik Umum Müdürlüğü. İstatistik Yıllı̆̆g 1939-1940.

T.C. Cumhurbaşkanlığ ${ }_{1}$ Devlet Arşivleri Başkanlığ 1 Cumhuriyet Arşivi (BCA).

T.C. İzmir Ticaret ve Sanayi Odası Mecmuası, Haziran 1930.

T.C. İzmir Vilayeti İstatistik Müdürlüğü. İstatistik Yıllı̆̆g 1932-1933. 
T.C. İzmir Vilayeti İstatistik Müdürlügüu. İstatistik Yılllı̆̆ 1933-1934.

Tatar, T. (2012). Osmanlı İmparatorluğunun sömürgeleşme sürecinde Levanten bir Kent: İzmir. [Doktora tezi], Ankara Üniversitesi.

TBMM Kanunlar Dergisi, 12 Haziran 1933.

TBMM Kanunlar Dergisi, 18 Haziran 1934.

TBMM Komisyon Raporu Sıra No: 235. İzmir liman ve körfez işlerinin hükümetçe idaresi hakkında 1/734 numaralı kanun layihası ve iktisat ve bütçe encümenleri mazbataları. TBMM Zabit Ceridesi, 18 Haziran 1934.

TBMM Zabit Ceridesi, 18 Haziran 1934.

Tekeli, İ. ve İlkin, S. (1977). 1929 Dünya Buhranında Türkiye'nin iktisadi politika arayışları. Orta Doğu Teknik Üniversitesi Yayınları.

Tekeli, İ. ve İlkin, S. (2009). Uygulamaya geçerken Türkiye'de devletçiliğin oluşumu. Bilge Kültür Sanat.

Tezel, Y. S. (2015). Cumhuriyet Döneminin iktisadi tarihi (1923-1950). Türkiye İş Bankası Kültür Yayınları.

Tokgöz, E. (2007). Türkiye'nin iktisadi gelişme tarihi (1914-2007). (8. Bs.). İmaj Yayınevi.

Topuz, H. (2009). XIX. yüzyılda Osmanlı limanlarından gerçekleşen ticaret hacmi ve diş ticaretine yönelik bir analiz (1878-1913). Süleyman Demirel Üniversitesi Vizyoner Dergisi, 1(1), 114-128.

United Nations Statistics Division. (1962). International trade statistics 19001960. 10 Ağustos 2020 tarihinde https://unstats.un.org/unsd/trade/imts/ Historical\%20data\%201900-1960.pdf adresinden erişildi.

Ünal, N. (2015a). İki Osmanlı liman kenti İzmir ve Selanik. İmge Kitabevi Yayınları.

Ünal, N. (2015b). Sorularla İzmir tarihi, İzmir Büyükşehir Belediyesi Kültür Yayını.

Varlık, B. (1980). 1930-1940 yılları arasında Türkiye'de tarımsal kooperatifler üzerine bir deneme. Ekonomik Yaklaşım Dergisi, 1(3), 101-133.

Varlık, B. (1981). Ahmet Hamdi Başar'da buğday meselesi. Ekonomik Yaklaşım Dergisi, 2(6), 85-105.

Yorulmaz, Ş. (1993). XIX. yüzyıl'da kozmopolit bir ticaret kenti: İzmir. Çă̆daş Türkiye Tarihi Araştırmaları Dergisi, 1(3), 133-148.

Yüksel, M. Ş. (2004). Arap kaynaklarında Timur. Ahmet Yesevi Üniversitesi Bilig Dergisi, (31), 85-126. 


\section{Etik kurul onayı}

Bu çalışma, Etik Kurul İzni Gerektiren Çalışmalar içerisinden; anket, mülakat, odak grup çalışması, gözlem, deney, görüşme teknikleri kullanılarak katılımcllardan veri toplanmasını gerektiren nitel ya da nicel yaklaşımlarla yürütülen her türlü araştırmalar, insan ve hayvanların (materyal/veriler dahil) deneysel ya da diğer bilimsel amaçlarla kullanılması, insanlar üzerinde yapılan klinik araştırmalar, hayvanlar üzerinde yapılan araştırmalar ve kişisel verilerin korunması kanunu gereğince retrospektif çalışmalardan herhangi biri dahilinde olmaması nedeni ile Etik Kurulu İzni gerektirmeyen çalışmalar arasında yer almaktadır.

\section{Çıkar çatışması beyanı}

Bu çalışmada herhangi bir potansiyel çıkar çatışması bulunmamaktadır. 


\section{Ekler}

Ek 1: İzmir Limanı'nın 1935 tarihli İzmir Limanı nizamnamesinde yer alan haritası
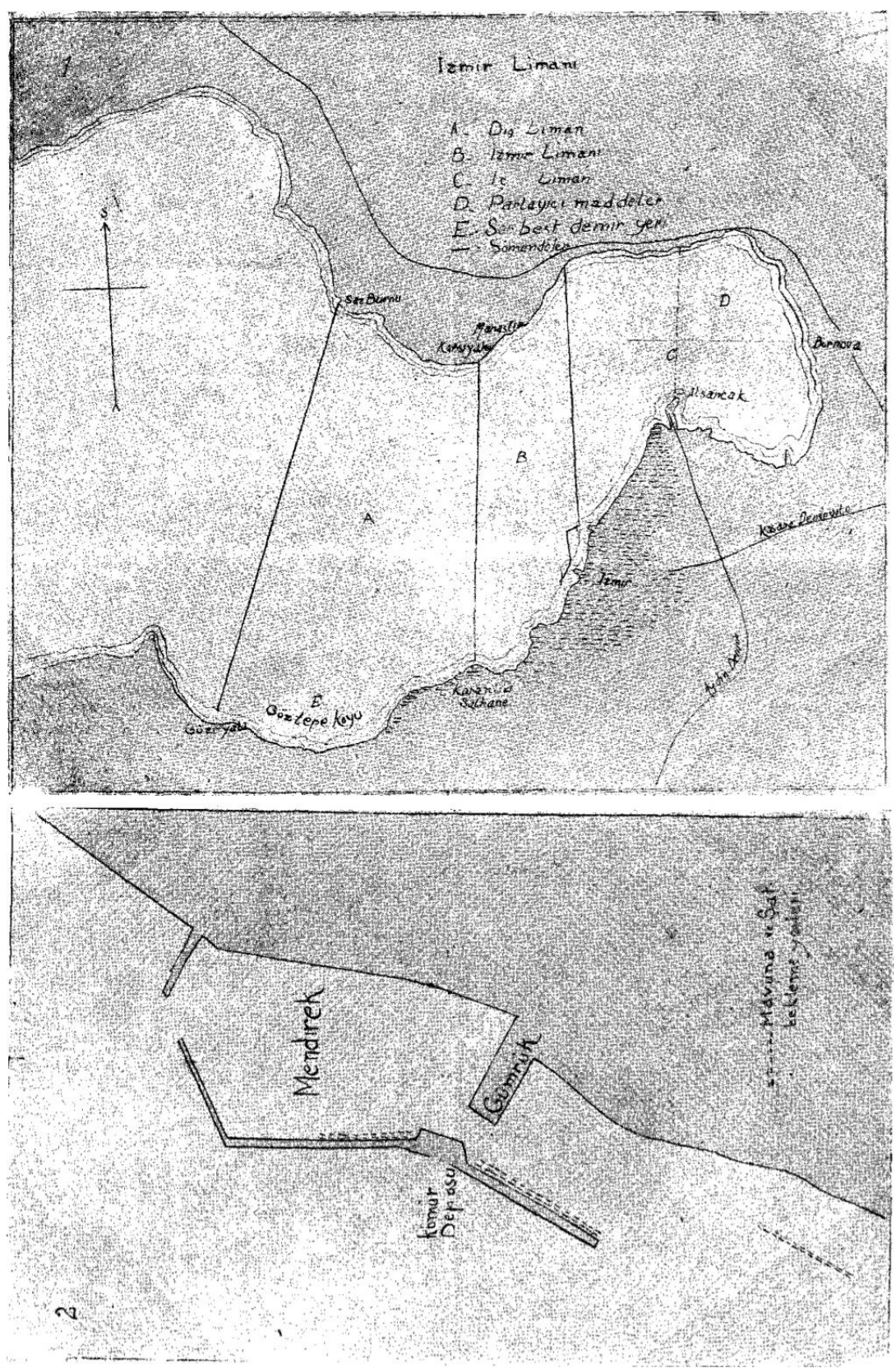

Kaynak: (14 Mart 1935). İzmir Limanı nizamnamesi hakkında kararname [1935].

Resmî Gazete. 
Ek 2: İzmir Rıhtımı Anonim Şirketinin defterlerinde yapılan incelemelere dair rapor

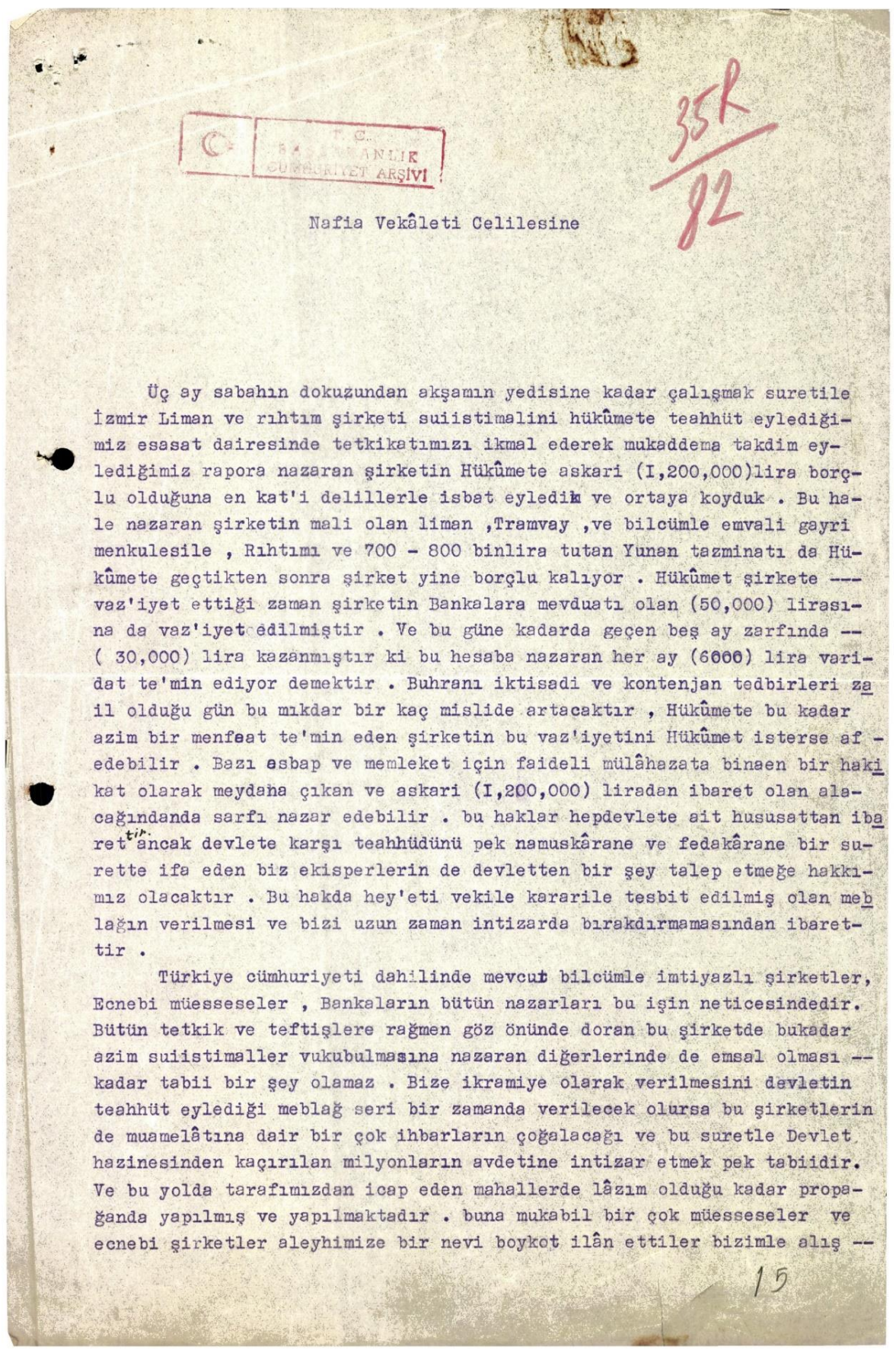




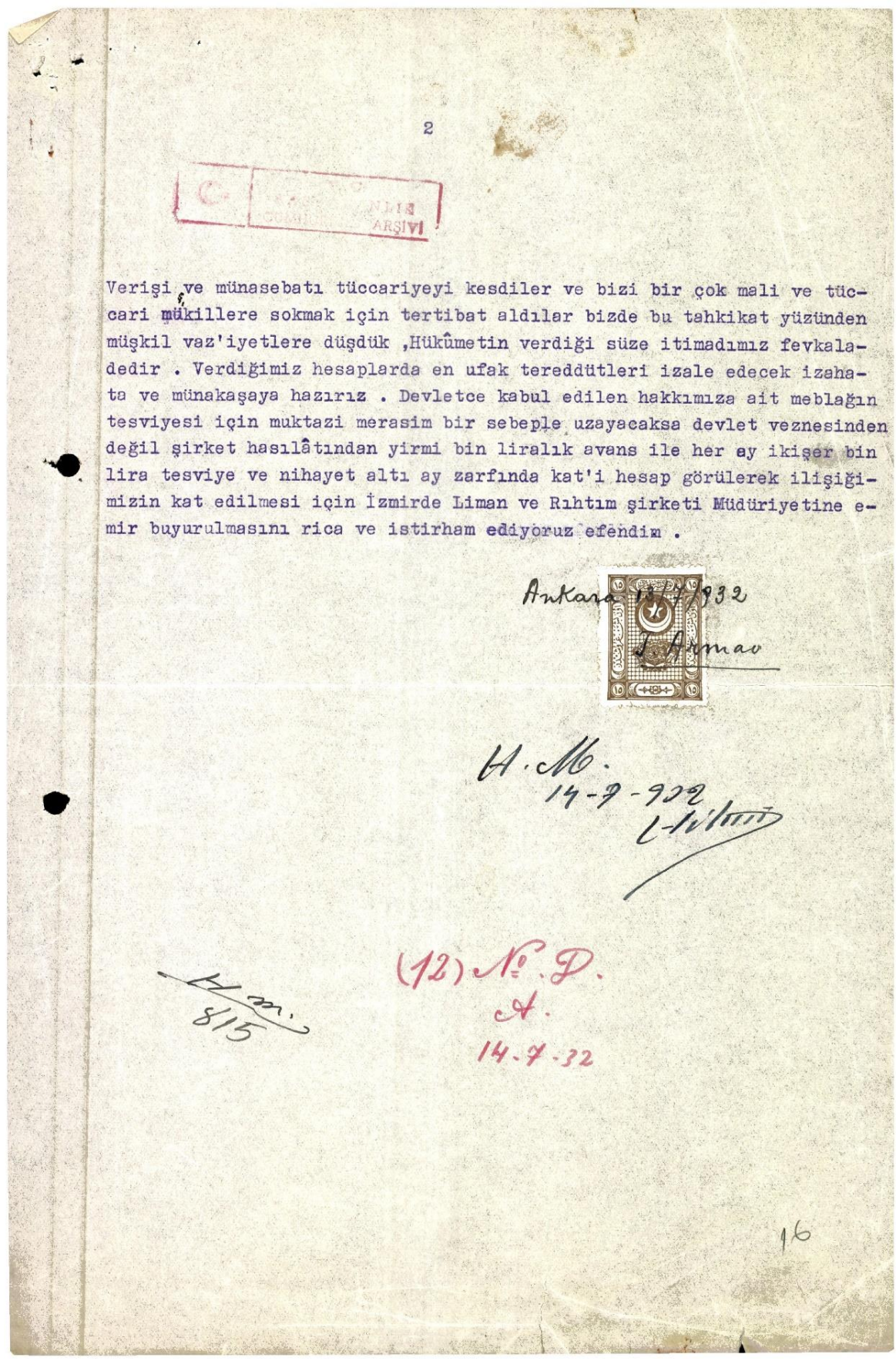

Kaynak: BCA, 230.0.0.0.131.20.3. 
Ek 3: 29 Nisan 1930 tarihli Anadolu gazetesinde yer alan İzmir Liman ve Körfez Şirketi ile ilgili karikatür
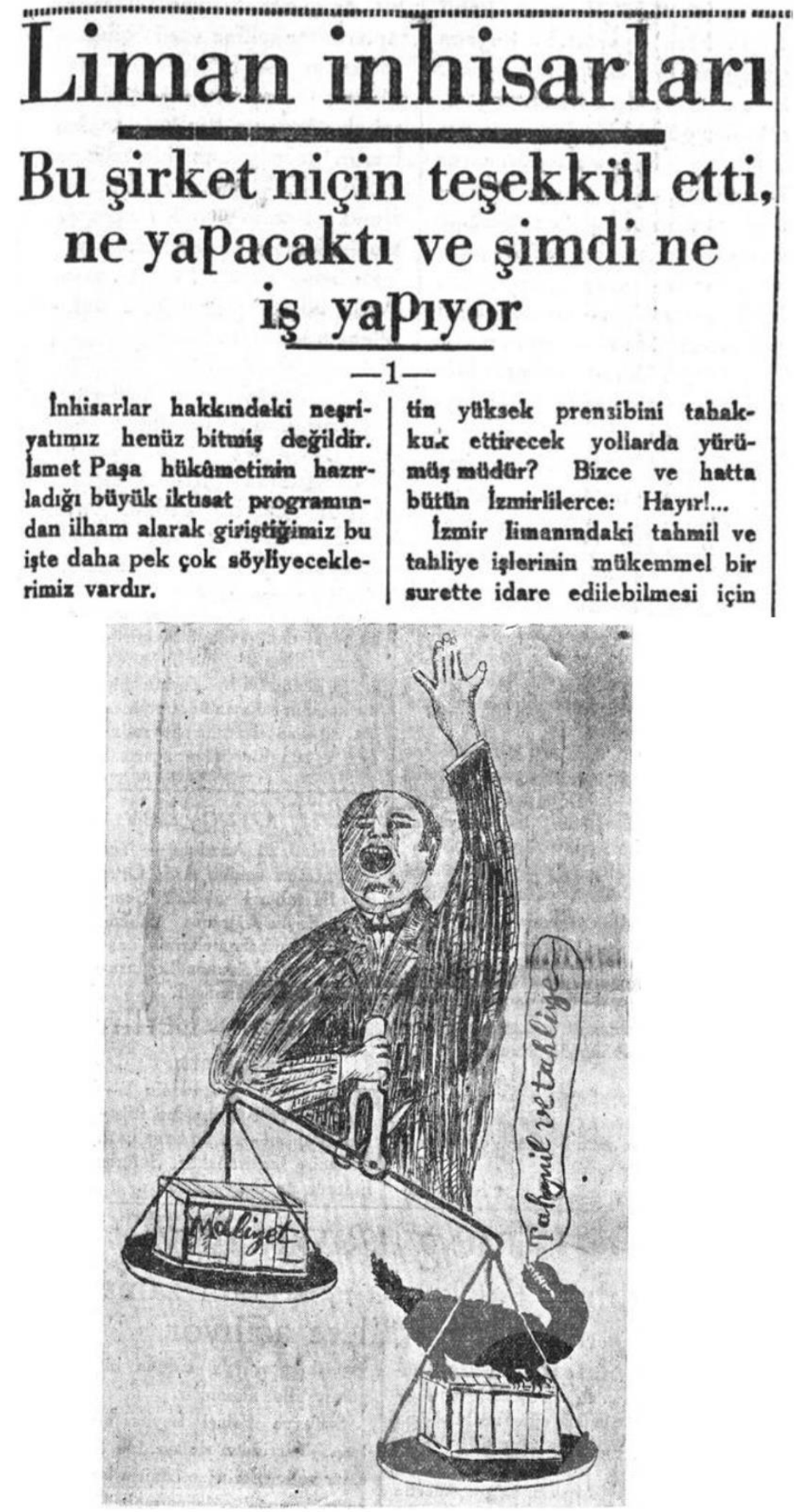

Kaynak: (29 Nisan 1930). Liman inhisarları. Anadolu. 